\title{
Soil Carbon Modelling in Salix Biomass Plantations: Variety Determines Carbon Sequestration and Climate Impacts
}

\author{
Saurav Kalita ${ }^{1} \mathbb{D}$, Hanna Karlsson Potter ${ }^{1}$, Martin Weih ${ }^{2}{ }^{\mathbb{D}}$, Christel Baum ${ }^{3, * \mathbb{C}}$, Åke Nordberg ${ }^{1}$ (1) \\ and Per-Anders Hansson ${ }^{1}$ \\ 1 Department of Energy and Technology, Swedish University of Agricultural Sciences, 75007 Uppsala, Sweden; \\ saurav.kalita@slu.se (S.K.); hanna.e.karlsson@slu.se (H.K.P.); ake.nordberg@slu.se (Å.N.); \\ per-anders.hansson@slu.se (P.-A.H.) \\ 2 Department of Crop Production Ecology, Swedish University of Agricultural Sciences, \\ 75007 Uppsala, Sweden; martin.weih@slu.se \\ 3 Soil Science, Faculty of Agricultural and Environmental Sciences, University of Rostock, \\ 18051 Rostock, Germany \\ * Correspondence: christel.baum@uni-rostock.de; Tel.: +49-381-498-3100; Fax: +49-381-498-3122
}

Citation: Kalita, S.; Karlsson Potter, H.; Weih, M.; Baum, C.; Nordberg, Å.; Hansson, P.-A. Soil Carbon Modelling in Salix Biomass Plantations: Variety Determines Carbon Sequestration and Climate Impacts. Forests 2021, 12, 1529. https://doi.org/10.3390/ f12111529

Academic Editor: Dirk Landgraf

Received: 20 September 2021

Accepted: 4 November 2021

Published: 6 November 2021

Publisher's Note: MDPI stays neutral with regard to jurisdictional claims in published maps and institutional affiliations.

Copyright: (c) 2021 by the authors. Licensee MDPI, Basel, Switzerland. This article is an open access article distributed under the terms and conditions of the Creative Commons Attribution (CC BY) license (https:// creativecommons.org/licenses/by/ $4.0 /)$.

\begin{abstract}
Short-rotation coppice (SRC) Salix plantations have the potential to provide fast-growing biomass feedstock with significant soil and climate mitigation benefits. Salix varieties exhibit significant variation in their physiological traits, growth patterns and soil ecology-but the effects of these variations have rarely been studied from a systems perspective. This study analyses the influence of variety on soil organic carbon (SOC) dynamics and climate impacts from Salix cultivation for heat production for a Swedish site with specific conditions. Soil carbon modelling was combined with a life cycle assessment (LCA) approach to quantify SOC sequestration and climate impacts over a 50-year period. The analysis used data from a Swedish field trial of six Salix varieties grown under fertilized and unfertilized treatments on Vertic Cambisols during 2001-2018. The Salix systems were compared with a reference case where heat is produced from natural gas and green fallow was the land use alternative. Climate impacts were determined using time-dependent LCA methodology — on a land-use (per hectare) and delivered energy unit (per $\mathrm{MJ}_{\text {heat }}$ ) basis. All Salix varieties and treatments increased SOC, but the magnitude depended on the variety. Fertilization led to lower carbon sequestration than the equivalent unfertilized case. There was no clear relationship between biomass yield and SOC increase. In comparison with reference cases, all Salix varieties had significant potential for climate change mitigation. From a land-use perspective, high yield was the most important determining factor, followed by SOC sequestration, therefore high-yielding fertilized varieties such as 'Tordis', 'Tora' and 'Björn' performed best. On an energy-delivered basis, SOC sequestration potential was the determining factor for the climate change mitigation effect, with unfertilized 'Jorr' and 'Loden' outperforming the other varieties. These results show that Salix variety has a strong influence on SOC sequestration potential, biomass yield, growth pattern, response to fertilization and, ultimately, climate impact.
\end{abstract}

Keywords: biomass production; life cycle assessment; climate impact; soil organic carbon; Salix; willow; short rotation coppice; genotypic difference

\section{Introduction}

It has been established that the current atmospheric concentrations of three major greenhouse gases (GHGs) - carbon dioxide $\left(\mathrm{CO}_{2}\right)$, methane $\left(\mathrm{CH}_{4}\right)$ and nitrous oxide $\left(\mathrm{N}_{2} \mathrm{O}\right)$, are at the highest levels estimated for the past 800,000 years [1]. Most of this increase has happened post 1750, which was the beginning of the Industrial Revolution. The most alarming trend is that the decadal rate of increase in atmospheric $\mathrm{CO}_{2}$ was highest in 2002-2011 since direct measurements began in 1958 [2]. There is consensus among the scientific community that the principal cause of this rapid increase is use of fossil fuels and 
land use change associated with the start of the Industrial Age. The increased atmospheric concentration of GHGs has enhanced radiative forcing, leading to higher average global temperatures and climate change.

Countries and organizations worldwide have set certain regulations and targets to limit the increase in average global temperatures to avoid the negative impacts of climate change. The European Commission has set targets to cut GHG emissions by at least $40 \%$ below 1990 levels and to increase renewable energy share to at least 32\% by 2030 [3]. The long-term strategy is to reach a climate-neutral EU by 2050 [4]. Sweden has made an ambitious commitment to phase out all GHG emissions completely by $2045[5,6]$. The climate crisis induced by increased GHG emissions has led to a quest for different strategies to mitigate the problem. Bioenergy from sustainable biomass can be part of a viable climate mitigation strategy by replacing fossil fuels for heat and electricity generation. At the global scale biomass accounted for $9 \%$ of renewable electricity generation and $96 \%$ of renewable heat generation in 2018 [7].

The cultivation of plant species such as Salix (willow) and Populus (poplar) in shortrotation coppice (SRC) systems has emerged as an interesting approach to sustainably produce renewable biomass [8,9]. Salix SRC systems are characterized by short growth cycles of 2-5 years, after which the stems are harvested, and shoots regrow from the stumps left in the soil [10]. SRC plantations can have a positive effect on soil organic carbon (SOC) sequestration, because of the addition of large amounts of root and leaf litter to the soil, which are better incorporated into the soil due to minimal soil disturbance compared with annual crops [11]. Salix propagates easily via cuttings and is well suited to growth in temperate and Arctic climatological conditions. Commercial plantations of Salix are gaining interest worldwide for use as a biomass crop, with the largest cultivated areas (as of 2015) in China and Argentina, followed by North America and Europe [12]. There is high interest in European countries such as Sweden, where commercial Salix plantations were established in the 1990s, with policies proposed to increase energy crop cultivation to 40,000 hectares by 2030 [13].

In Sweden, the area under SRC plantations reached a peak of about 18,000 hectares in the mid-1990s, which decreased to about 12,000 hectares by 2015 [14,15]. This was attributed to a combination of factors such as poor management, inefficient policy and low prices - which meant that the practical results did not meet the high expectations $[16,17]$. New varieties and better management practices adapted to Swedish conditions have emerged in the past two decades. These, combined with the ambitious Swedish emission reduction targets, make SRC Salix an interesting prospect for biomass feedstock in the Swedish context.

The SOC sequestration potential of SRC plantations is gaining attention among researchers for its climate mitigation effects. Multiple studies [18-22] have found that SRC Salix systems sequester more carbon than conventional cropping systems. However, the SOC sequestration of Salix established on grasslands is more uncertain and can be lower $[23,24]$. The magnitude and potential for SOC change depend on previous land use, soil and climate conditions $[18,24,25]$. This, combined with the different soil profile depths considered in different studies leads to variation in reported SOC stock change rates. Long-term field data, and especially those on belowground biomass production rates, are necessary to validate and improve the accuracy of SOC sequestration estimates for SRC Salix plantations under different growth and soil conditions.

Biomass for bioenergy utilization can be considered carbon neutral as $\mathrm{CO}_{2}$ emitted from its conversion phase is recaptured by new growth. However, there is a need to assess the climate impact in a system perspective including changes in SOC and land use, and impacts from site preparation, production of inputs, machinery operations, transports and energy conversion. Quantification of the potential effects and impacts of biomass use over spatial and temporal horizons is needed to ensure its sustainability. 
There are several tools for environmental impact evaluation, and one of the most commonly used is Life Cycle Assessment (LCA). LCA is a well-established and standardized tool for estimation of potential environmental impacts from a product or service over its whole lifespan. The LCA methodology was originally designed for industrial processes and products but has been expanded in recent decades to evaluate and compare agricultural, forestry and bioenergy processes and products [26,27]. In the context of bioenergy production system evaluation, LCA helps by expanding the perspective beyond the production system itself. This is important as the environmental consequences of a bioenergy production system frequently depend more on the impacts on other parts of the value chain than on the production system itself. Thus, the broad system perspective makes LCA a suitable tool for planning of bioenergy systems and policymaking, especially in the context of the potential effects of bioenergy production systems on climate change mitigation. However, when modelling large and often complicated systems in LCA studies, parts of the data are often more uncertain and some subjective aspects may be handled in order to reach the broad system perspectives $[28,29]$. These limitations are not unique to LCA, and similar problems occur even in other methods for environmental systems analysis. The decisions on data quality requirements play an important role in the results of the assessment. Ambitions about completeness of data must be balanced against availability of resources and workload. These are intrinsic and accepted aspects of LCA studies, as long as the relevance, data quality and relevant major assumptions are appropriately described [30]. The LCA methodology is constantly evolving as understanding of climate and environmental impacts develops.

The most common climate impact metric used in LCA is global warming potential $\left(\mathrm{GWP}_{100}\right)$, which is based on radiative forcing and captures the integrated impacts over a single time horizon of 100 years [31]. It does not capture the effect of timing and persistence of GHG fluxes and temporal changes in SOC [32]. It does not represent the actual impacts on ecosystems such as temperature change, sea level change or biodiversity loss.

Using a time-dependent method can counter this by expressing the climate metric as a function of time. Several studies have developed such alternative methods and applied them in LCA to capture the emissions and fluxes of carbon flows between the atmosphere, biomass and soil [17,32-34]. An absolute time-dependent climate metric such as the absolute global temperature change potential $(\Delta T s)$ developed by Ericsson et al. [35] represents the impact on global mean surface temperature from emission or removal of a GHG at a particular point in time. This can aid in better understanding of climate impacts of bioenergy as biomass systems capture and emit carbon at different points in time. Several LCA studies have assessed Salix cultivation for bioenergy utilization [17,32,33,36-40]. However, studies looking at the magnitude of impact of differences between Salix varieties on the overall bioenergy system are rare.

Differences between Salix varieties can have a significant impact on physiological traits, biomass quality, growth patterns and soil ecology. Weih and Nordh [41] showed that key traits and shoot biomass production are variety-specific and that there is a need to account for these variety differences at the field level. Adegbidi et al. [42] found that biomass production, nutrient use efficiency and nutrient removal are strongly influenced by variety in Salix plantations. Cunniff et al. [43] observed significant differences in allocation between aboveground and belowground biomass in different varieties and at different locations in the UK. Data from Salix field trials in Sweden have demonstrated that the effects of fertilization on soil ecology are also affected by variety [44]. Salix varieties have been found to differ significantly in their response to fertilization and in carbon storage potential in shoots and soil [44]. 
Despite of the many plant-and field-scale reports indicating significant impacts of Salix varieties on plant traits that potentially affect their environmental performance, there is a lack of systems-scale research (such as LCAs) accounting for these differences. Thus, there is a need to address the differences between Salix varieties regarding the impact on soil carbon sequestration and climate impact when assessing bioenergy systems in a life cycle perspective

This study aimed to analyze the effects of Salix variety and fertilization treatment on SOC dynamics, and subsequent effects on climate impacts of Salix cultivation for bioenergy on a commercial scale, with a 50-year time horizon. A field trial established in 2001 is the source of the harvest and SOC data for the selected Salix varieties in this study $[44,45]$. Unfortunately, root biomass data over time from field-grown trees were not available from the trials used here, and we therefore used indirect methods to estimate root biomass allocation over time from published reports using pot and lysimeter experiments, in which root biomass can be assessed more easily. Other data are either taken from literature and studies on Salix systems where available, or based on assumptions derived from other biomass systems.

Specific objectives of the study were to:

1. Estimate the potential for soil carbon sequestration for the selected Salix varieties under the specific site conditions of Vertic Cambisols by using soil carbon modelling;

2. Assess the climate impact from utilizing Salix grown on existing fallow land as feedstock in an incineration plant using two metrics- $\mathrm{GWP}_{100}$ and a time-dependent climate metric $(\Delta T s)$;

3. Calculate the energy balance and performance (in terms of energy ratio) for the selected Salix varieties.

It is expected that quantification of the magnitude of varietal effects will highlight the importance of their inclusion in systems analysis studies of bioenergy. The intention was to provide a basis for comparison of Salix varieties in terms of energy and climate performance, which can aid in the consideration of optimal Salix variety selection for a particular purpose, e.g., maximized carbon sequestration potential.

We believe that studies like this investigation will motivate the need for varietyand location-specific root and belowground data to make realistic, accurate and detailed assessments of the environmental performance of bioenergy systems.

\section{Materials and Methods}

The effect of Salix variety on the climate impact and energy performance of a Salixbiomass production system under Swedish conditions (Uppsala region) was analyzed using LCA methodology. Two functional units (FU) of $1 \mathrm{MJ}$ of heat and 1 hectare of land were chosen to describe the two different functions of the system-generation of heat and use of land as a resource for mitigating climate impacts. The energy FU compares the relative impact of using the Salix varieties as an energy source, while the land FU unit compares the different impacts from a land use perspective considering land as a restricted resource.

The climate impact calculation considers three major GHGs $\left(\mathrm{CO}_{2}, \mathrm{~N}_{2} \mathrm{O}\right.$ and $\left.\mathrm{CH}_{4}\right)$ and is expressed in terms of two metrics-global warming potential $\left(\mathrm{GWP}_{100}\right)$ and a timedependent climate impact ( $\Delta T s)$ as defined in [35], with a one-year time step. The flux of carbon in the soil due to addition and decomposition of biomass was modelled with the carbon model ICBM developed by Andrén and Kätterer [46]. Annual net flux of the selected GHGs was estimated for each source and sink, and the associated emission impulses were based on the timing of the emissions. 


\subsection{Plant Material, Field Trial and Data Collection}

The analysis was based on data collected from a field trial during the period 2001-2017 at Pustnäs, near Uppsala in central Sweden by Weih and Nordh [45]. The following six commercial Salix varieties were part of the study: 'Björn' (Salix schwerinii E. Wolf. $\times$ S. viminalis L.), 'Gudrun' (S. burjatica Nasarow $\times$ S. dasyclados Wimm.), 'Jorr' (S. viminalis), 'Loden' (S. dasyclados), 'Tora' (S. schwerinii $\times$ S. viminalis) and 'Tordis' $((S$. schwerinii $\times$ S. viminalis $) \times$ S. viminalis $)$. There were two experimental treatments - fertilized (approx. $100 \mathrm{~kg} \mathrm{~N}, 14 \mathrm{~kg} \mathrm{P}, 47 \mathrm{~kg} \mathrm{Kha}^{-1} \mathrm{yr}^{-1}$ ) and unfertilized. Plots were $6.75 \mathrm{~m} \times 7.00 \mathrm{~m}$ in size and contained 84 plants each, corresponding to a planting density of about 18,000 plants per hectare. Each variety and treatment had four replicate plots. The dominating soil type was a vertic cambisol with a sandy loam as topsoil (0-20 cm soil depth) with $66 \%$ sand, $16 \%$ silt and $18 \%$ clay. Initial SOC content at $0-10 \mathrm{~cm}$ soil depth was $11.1 \mathrm{~g} \mathrm{~kg}^{-1}$, with a bulk density of $1.3 \mathrm{~g} \mathrm{~cm}^{-3}$. Further details of the field trial can be found in Weih and Nordh [45].

After establishment of the plantation in 2001, the plantation was managed in three-year cutting cycles with shoots harvested during winter in 2004, 2007, 2010, 2013 and 2016. Mean air temperature during the growing season (April to October) in the years relevant to this study was $12.5^{\circ} \mathrm{C}$, and the corresponding mean annual precipitation sum was $841 \mathrm{~mm}$ [44].

For the present analysis, the average yield for the first harvest (2004) and for subsequent harvests (average value for 2007-2016 harvests) were calculated. The first yield after planting is usually lower, as the plant root system is still establishing. The shoot growth and biomass yield figures after the field measurement period (post-2017) were assumed to follow the average values calculated from the field trial data. Table 1 presents the average harvest values from the field study used as input to the modelling work.

Table 1. Average harvested biomass yield (dry weight, DW) and standard deviation (SD) of the six commercial Salix varieties grown under two fertilization regimes in central Sweden from 2001 to 2018. F0 and F+ refer to the unfertilized and fertilized treatment, respectively.

\begin{tabular}{ccccc}
\hline \multirow{2}{*}{$\begin{array}{c}\text { Variety and } \\
\text { Treatment }\end{array}$} & \multicolumn{2}{c}{ 1st Harvest } & \multicolumn{2}{c}{ 2nd-5th Harvest } \\
\cline { 2 - 5 } & $\begin{array}{c}\text { Average } \\
\text { (DW } \mathbf{~ M g ~ h a - 1 ) ~}\end{array}$ & SD & $\begin{array}{c}\text { Average } \\
\text { (DW Mg ha-1) }\end{array}$ & SD \\
\hline Björn F0 & 7.4 & 3.8 & 31.9 & 8.3 \\
Björn F+ & 15.5 & 4.3 & 42.7 & 16.0 \\
Gudrun F0 & 8.8 & 4.1 & 20.8 & 5.9 \\
Gudrun F+ & 11.6 & 1.2 & 20.6 & 5.2 \\
Jorr F0 & 4.5 & 1.3 & 14.4 & 7.6 \\
Jorr F+ & 16.9 & 0.9 & 36.9 & 6.0 \\
Loden F0 & 3.9 & 1.2 & 14.4 & 4.1 \\
Loden F+ & 10.4 & 4.9 & 18.3 & 10.2 \\
Tora F0 & 6.7 & 4.7 & 18.2 & 11.1 \\
Tora F+ & 16.6 & 6.1 & 38.3 & 13.0 \\
Tordis F0 & 10.8 & 5.1 & 28.5 & 9.0 \\
Tordis F+ & 19.8 & 6.4 & 48.5 & \\
\hline
\end{tabular}

The field site was ploughed shortly before planting of the Salix stem cuttings. The soil in each plot was sampled (five replicates per plot) with a soil corer ( $3 \mathrm{~cm}$ diameter), to a depth of $10 \mathrm{~cm}$ in spring 2001 and to a depth of $20 \mathrm{~cm}$ in 2018. The initial soil sampling was performed prior to laying out the plots. The field site is characterized by a flat surface without relief-promoted erosion, which contributed to the lack of significant differences in soil properties between the different plots. An additional follow-up soil sampling in 2002 showed no significant differences in the bulk density and SOC content among the plots. As such, the ploughing did not cause a measurable difference between the first (2001) and second year (2002). The SOC content in the $0-10 \mathrm{~cm}$ layer was recorded and is reported by Baum et al. [44], who provide full details of the soil sampling and analysis procedures. 
As the plough depth was about $25 \mathrm{~cm}$ during the year of establishment of the field trial, the topsoil (0-20 cm soil depth) was assumed to be homogenous and to have similar characteristics. Hence, the initial SOC stock in the 10-20 cm soil layer in 2001 was assumed similar to that in the $0-10 \mathrm{~cm}$ soil layer. The bulk density in 2018 had not changed significantly from the initial value of $1.3 \mathrm{~g} \mathrm{~cm}^{-3}$, which can be expected as consequence of combined lack of loosening by tillage under the perennial crops, but improved aeration of the soil by increased SOC content. The SOC stock in the 10-20 cm soil layer from 2018 was analyzed following the same methodology as was described by Baum et al. [44] for the $0-10 \mathrm{~cm}$ soil layer. The resulting SOC stocks in the $0-10 \mathrm{~cm}, 10-20 \mathrm{~cm}$ and $0-20 \mathrm{~cm}$ layers in 2001 and 2018 are displayed in Table 2. The reduction in SOC content in the 10-20 cm layer for some of the Salix varieties is not unexpected under SRC as evidenced by similar results reported by Kahle et al. [47].

Table 2. Soil organic carbon stock $\left(\mathrm{Mg} \mathrm{ha}^{-1}\right)$ in the $0-10$ and $10-20 \mathrm{~cm}$ soil layers measured in field trials on six Salix varieties at Pustnäs, Sweden, in 2001 (pre-establishment) and in 2018. F0 and F+ refer to the unfertilized and fertilized treatments respectively.

\begin{tabular}{|c|c|c|c|c|c|c|c|}
\hline \multirow[t]{2}{*}{$\begin{array}{l}\text { Variety and } \\
\text { Treatment }\end{array}$} & \multicolumn{3}{|c|}{$\begin{array}{l}\text { Soil Carbon Stock } 2001 \\
\left(\mathrm{Mg} \mathrm{ha}^{-1)}\right.\end{array}$} & \multicolumn{3}{|c|}{$\begin{array}{l}\text { Soil Carbon Stock } 2018 \\
\left(\mathrm{Mg} \mathrm{ha}^{-1)}\right.\end{array}$} & \multirow{2}{*}{$\begin{array}{c}\begin{array}{c}\text { Increase in } \\
\text { SOC Stock } \\
\left(\mathrm{Mg} \mathrm{ha}^{-1}\right)\end{array} \\
0-20 \mathrm{~cm}\end{array}$} \\
\hline & $0-10 \mathrm{~cm}$ & $10-20 \mathrm{~cm}$ & $0-20 \mathrm{~cm}$ & $0-10 \mathrm{~cm}$ & $10-20 \mathrm{~cm}$ & $0-20 \mathrm{~cm}$ & \\
\hline Björn F0 & 14.4 & 14.4 & 28.9 & 24.3 & 15.3 & 39.7 & 10.8 \\
\hline Björn F+ & 14.4 & 14.4 & 28.9 & 20.9 & 12.1 & 33.0 & 4.2 \\
\hline Gudrun F0 & 14.4 & 14.4 & 28.9 & 22.3 & 21.3 & 43.6 & 14.7 \\
\hline Gudrun $\mathrm{F}+$ & 14.4 & 14.4 & 28.9 & 21.9 & 12.8 & 34.8 & 5.9 \\
\hline Jorr F0 & 14.4 & 14.4 & 28.9 & 31.7 & 18.6 & 50.3 & 21.5 \\
\hline Jorr F+ & 14.4 & 14.4 & 28.9 & 27.5 & 14.3 & 41.8 & 12.9 \\
\hline Loden F0 & 14.4 & 14.4 & 28.9 & 26.8 & 17.3 & 44.2 & 15.3 \\
\hline Loden F+ & 14.4 & 14.4 & 28.9 & 20.5 & 12.7 & 33.2 & 4.4 \\
\hline Tora F0 & 14.4 & 14.4 & 28.9 & 25.4 & 16.1 & 41.6 & 12.7 \\
\hline Tora F+ & 14.4 & 14.4 & 28.9 & 25.8 & 14.2 & 40.0 & 11.2 \\
\hline Tordis F0 & 14.4 & 14.4 & 28.9 & 26.9 & 16.9 & 43.9 & 15.0 \\
\hline Tordis F+ & 14.4 & 14.4 & 28.9 & 23.9 & 14.6 & 38.5 & 9.6 \\
\hline
\end{tabular}

\subsection{System Boundaries}

The system studied comprised the steps from preparation of the field site for Salix cultivation to production of heat in a boiler in a heating plant (Figure 1). Energy flows and emissions from field operations, production of inputs, biomass transportation and thermochemical conversion were included within the system boundaries. Downstream losses and emissions after production of heat and ash at the incineration plant were considered as outside the system boundaries. Belowground changes and biomass inputs (from leaf, stumps, fine roots and coarse roots) to $20 \mathrm{~cm}$ depth were within the system boundaries as the SOC values from the field studies were determined with accuracy within the $0-20 \mathrm{~cm}$ soil layer. Highest litter input from fine roots and leaf litter are within this soil profile [48]. As the SOC changes in the sub-20-cm-profile are not part of the study system, a higher total carbon sequestration in the complete soil profile can be assumed. 


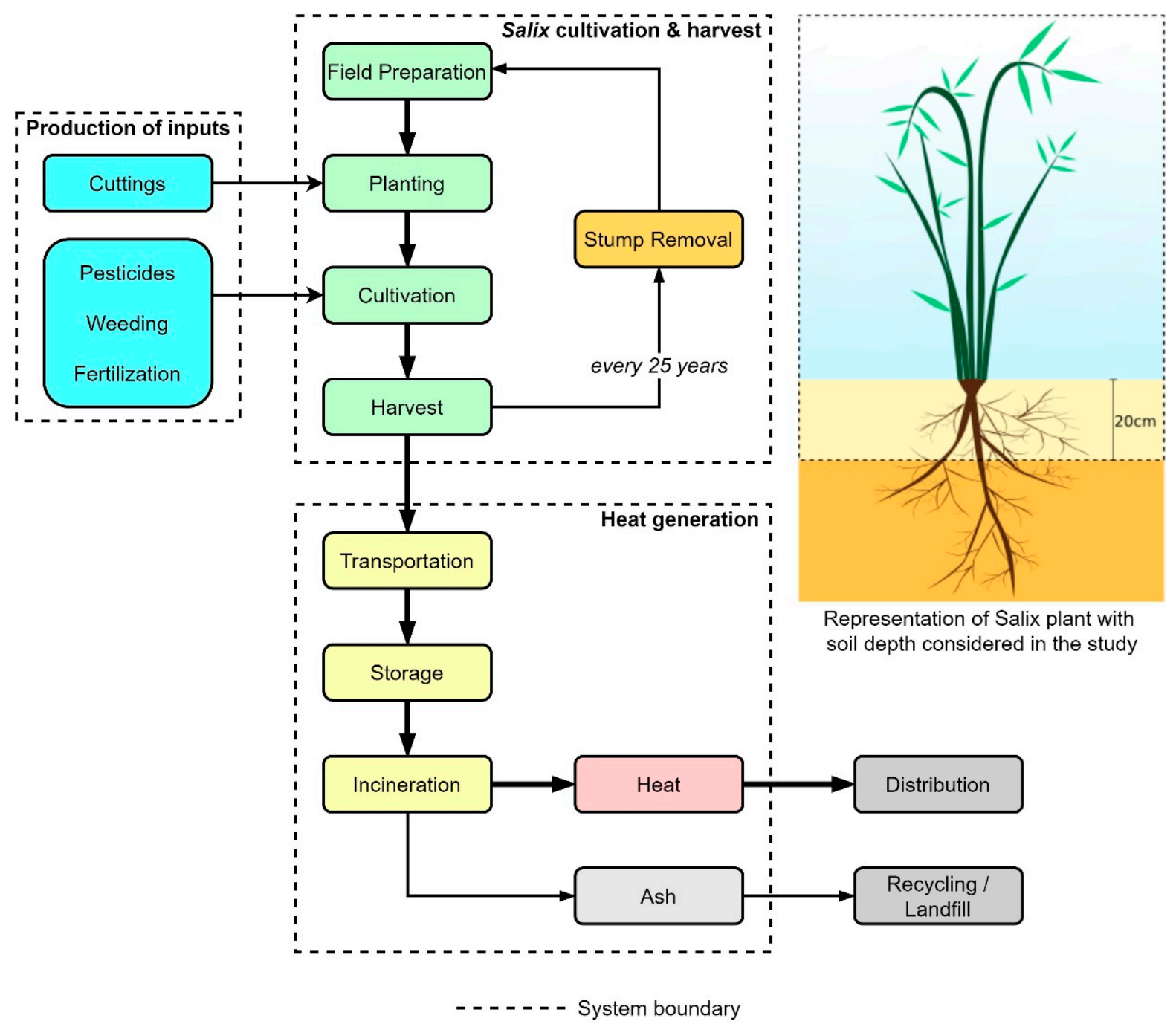

Figure 1. System boundaries (dotted lines) showing the processes considered within the study. Greenhouse gas and energy fluxes associated with the processes within the system boundaries were included in the analysis.

\subsection{Field Operations and Management}

The SRC Salix system followed a typical three-year cutting cycle, with the Salix harvested and chipped on-site at the end of every third growth cycle. The Salix then regrew from the stumps left in the field. According to current practical recommendations [49], one rotation period was assumed to last 25 years, after which the stumps would be broken up and removed and a new rotation would be established with new cuttings. The study period for the system was set to 50 years, which resulted in two rotation cycles. Technologies and management practices were assumed unchanged during this period. The data and assumptions used to calculate energy and emissions associated with the production of inputs and processes can be found in the Supplementary Material (Tables S6 and S7).

The harvest period for SRC systems is usually during winter months because the biomass is drier, the plant is dormant and the hard frozen soil provides a higher machinery carrying capacity [49,50]. It was assumed that the conventional method of harvesting and direct chipping was followed. Thereafter, the chips were transported to a heating plant for production of heat. The average road transportation distance was set as $40 \mathrm{~km}$ in this study.

\subsection{Thermochemical Conversion}

The higher heating value (HHV) of the Salix chips was considered to be $19.9 \mathrm{GJ} / \mathrm{Mg}$ $\mathrm{DM}$ (dry and ash-free), based on which the lower heating value (LHV) adjusted for moisture content was calculated [51,52]. The average storage period of the chips was 30 days, during 
which $3 \%$ dry matter loss occurred. The heating plant produces heat from biomass incineration and is equipped with flue gas condensation, which raises the overall efficiency. The energy efficiency for heat and flue gas condensation is $84 \%$ and $10 \%$ respectively (LHV basis), which gives an overall energy efficiency of $94 \%$. The ash produced from biomass incineration was assumed to be transported by road for an average distance of $100 \mathrm{~km}$. Calculation of ash quantities was on ash content of $3 \%$ in the Salix biomass [53]. The downstream processing and end-use of the ash were deemed outside the system boundaries.

\subsection{Reference System}

The reference energy system in this study was a fossil fuel-based energy generation system. A natural-gas-powered incineration plant supplied heat equivalent to the amount generated in the same year from the SRC Salix system. The alternative land use scenario was green fallow. The modelled SOC increase and use of fossil fuel for topping the land annually were included in the LCA. Assumptions concerning emissions and energy modelling are included in the Supplementary Material (Table S8).

\subsection{Energy Performance Indicator}

Energy performance was quantified by the indicator energy ratio $(E R)$, which is the ratio between the delivered usable energy (thermal energy in this case) and the total primary energy input to the system [54,55]:

$$
E R=\frac{\text { Delivered energy }\left(E_{\text {out }}\right)}{\text { Energy Inputs }\left(E_{\text {in }}\right)}
$$

The delivered energy $\left(E_{\text {out }}\right)$ is the energy produced (as heat) from the heating plant. Energy inputs $\left(E_{i n}\right)$ is the sum of all primary energy inputs associated with field processes and management, machinery operation, and production of inputs (fertilizers, pesticides and cuttings). $E_{\text {in }}$ excludes the energy contained in the Salix biomass produced by cultivation.

This means that the losses in the thermochemical conversion process are excluded, but they indirectly reduce the delivered energy $\left(E_{\text {out }}\right)$. The ER metric is dimensionless and describes the useful energy produced per unit of energy consumed.

\subsection{Mineral Fertiliser}

Addition of nitrogen in the form of mineral fertilizers and biomass entering the soil lead to direct and indirect emissions of $\mathrm{N}_{2} \mathrm{O}$. The amount of fertilizer was set according to the levels used in the field studies, where all fertilized treatment plots received $100 \mathrm{~kg} \mathrm{~N}$, $14 \mathrm{~kg} \mathrm{P}, 47 \mathrm{~kg} \mathrm{~K}$ per hectare annually, excluding the year of establishment [44].

The direct $\left(\mathrm{N}_{2} \mathrm{O}_{\text {direct }}\right)$ and indirect $\left(\mathrm{N}_{2} \mathrm{O}_{\text {indirect }}\right)$ emissions were calculated as:

$$
\begin{gathered}
N_{2} O_{\text {direct }}=E F_{N} \cdot\left(N_{\text {applied }}+N_{\text {litter }}+N_{\text {roots }}\right) \cdot \frac{44}{28} \\
N_{2} \mathrm{O}_{\text {indirect }}=N_{\text {applied }} \cdot\left(F_{A} \cdot E F_{D}+N_{\text {leached }} \cdot E F_{L}\right) \cdot \frac{44}{28}
\end{gathered}
$$

where $N_{\text {applied }}$ is the nitrogen applied by mineral fertilizer, $N_{\text {litter }}$ and $N_{\text {roots }}$ is the nitrogen contained in aboveground litter and roots respectively, and $N_{\text {leached }}$ is the nitrogen lost by leaching. $E F_{N}, E F_{D}$ and $E F_{L}$ are emission factors for direct emissions from applied nitrogen, indirect emissions from volatilization and re-deposition, and leaching respectively. $F_{A}$ represents the fraction of applied nitrogen emitted as ammonia. The fraction $\frac{44}{28}$ converts nitrogen to $\mathrm{N}_{2} \mathrm{O}$. The emissions are calculated using default parameter values from IPCC [56], and are presented in Table A1, Appendix A. The same methodology was followed to calculate emissions from the fallow reference case.

$\mathrm{N}_{2} \mathrm{O}$ emissions from biomass residues were based on the nitrogen content in Salix leaf litter reported for the selected varieties by Weih and Nordh [41] (details in Table S4 in Supplementary Material) and for stems as $0.43 \%$ (of total solids) [41]. Root nitrogen content 
was calculated from a dataset by Manzoni et al [57]. The estimated mean nitrogen content of roots from plants with low and high fertilization was $0.83 \%$ and $1.76 \%$ (of total solids) respectively (Table S5 in Supplementary Material). There are few studies on nitrogen content between different plant components, especially among different Salix varieties.

\subsection{Soil Carbon}

Soil carbon balances were calculated using the regional Introductory Carbon Balance Model (ICBMr) [46,58]. While the field trials provide measured SOC change for the first 17 years, the soil carbon modelling was used to estimate the SOC sequestration over the study period of 50 years. The model calculates the carbon flux based on variable annual inputs and regional differences. The ICBM model compartmentalizes the soil carbon into two pools, a young pool (Y) and an old pool (O), and the dynamics are governed by five parameters $\left(i, k_{y}, k_{o}, h\right.$ and $\left.r_{e}\right)$. The annual carbon input, denoted $i$, enters the young pool primarily in the form of leaf litter and dead roots. Both the young and old carbon pools undergo decomposition according to first-order kinetics as determined by decay constants $k_{y}$ and $k_{o}$, respectively. The humification coefficient $h$ denotes the fraction of the young pool that enters the old pool, while the remainder returns to the atmosphere as $\mathrm{CO}_{2}$ emissions. The variable $r_{e}$ represents the effect of external factors (mostly climatic and edaphic) on the decomposition rates. The initial calibration of the model was carried out using data from the Ultuna long-term field trial [59]. The ICBM parameters from the long-term trials are the basis of the parameters used in our study for SOC modelling as the long-term field trials are in the same region as our study.

The humification factor $(h)$ varies depending on biomass quality and studies have indicated that roots can contribute more to SOC than aboveground residues [60]. Salix fine roots specifically have been shown to have higher turnover rates [48]. Therefore, the model was modified to represent the two different input biomass types—aboveground inputs $\left(i_{a}\right)$ and belowground inputs $\left(i_{b}\right)$, with separate humification coefficients $\left(h_{a}\right.$ and $\left.h_{b}\right)$. Hence, there were two parallel young pools, a young pool representing the aboveground biomass input $\left(Y_{a}\right)$ and a young pool representing the belowground input $\left(Y_{b}\right)$. Equations (4) and (5) were used to calculate the SOC stock with an annual time step:

$$
\begin{gathered}
Y_{[a, b]}(t)=\left(Y_{[a, b]_{t-1}}+i_{[a, b]_{t-1}}\right) * \exp ^{-k_{y} r_{e}} \\
O(t)=\left(O_{t-1}-\left(\frac{h_{a} \cdot k_{y}}{\left(k_{o}-k_{y}\right)}\left(Y_{a_{t-1}}+i_{a_{t-1}}\right)+\frac{h_{b} \cdot k_{y}}{\left(k_{o}-k_{y}\right)}\left(Y_{b_{t-1}}+i_{b_{t-1}}\right)\right)\right) \cdot \exp ^{-k_{o} r_{e}} \\
+\left(\frac{h_{a} \cdot k_{y}}{\left(k_{o}-k_{y}\right)}\left(Y_{a_{t-1}}+i_{a_{t-1}}\right)+\frac{h_{b} \cdot k_{y}}{\left(k_{o}-k_{y}\right)}\left(Y_{b_{t-1}}+i_{b_{t-1}}\right)\right) \cdot \exp ^{-k_{y} r_{e}}
\end{gathered}
$$

The aboveground input, $i_{a}$, consists of the leaf litter. The belowground input, $i_{b}$, consists of the yearly fine root turnover and the accumulated coarse roots and stumps broken up and added to the soil after each 25-year rotation. The sum of the young and old pools represents the total SOC content at the specific point in time. Based on Kätterer et al. [60], $h_{b}$ was assumed to be 2.3 times the value of $h_{a}$. The parameters were estimated from previous SOC studies $[17,33,35,38]$ on Salix using the same methodology. The parameter details of the ICBM model are included in supplementary material (Tables S1 and S2).

\subsection{Biomass Production Allocation}

The standing biomass in Salix plants was divided into two major pools, aboveground and underground. The aboveground pool consisted of the stems $(S)$ and leaves $(L)$, while the underground pool consisted of the fine roots $(F)$ and coarse roots $(C)$. The stump material was included in the coarse root pool. The biomass growth allocation for these pools in a 3-year growing cycle are included in the Supplementary Material (Table S3). The 
ratio of 3-year accumulated net primary production (NPP) of aboveground biomass to belowground biomass, denoted as $\eta$ was calculated as:

$$
\eta=\frac{S+L}{F+C}=\frac{(1+a) S}{(1+b) F}
$$

where $S, L, F$ and $C$ are the net production of stems, leaves, fine roots and coarse roots (including stumps), respectively over the 3-year cutting cycle period, $a$ is the ratio of leaves to stems and $b$ is the ratio of coarse roots to fine roots.

The differences in growth patterns between the various Salix varieties and treatments can be expected to lead to variation in values of $\eta$ between them. Thus, varying the ratio $\eta$ would lead to different input parameters $\left(i_{a}\right.$ and $\left.i_{b}\right)$, resulting in different SOC values calculated by the ICBM model. This would lead to differences in biomass input between the varieties and variations in SOC accumulation. The ratios $a$ and $b$ were determined from lysimeter studies on Salix growth by Rytter [61] to be 0.244 and 0.238 , respectively, and are considered to remain unchanged between the different Salix varieties. Introduction of the factor $\eta$ was an attempt to represent the impact of genetic differences between Salix varieties on plant growth and biomass allocation.

Rytter and Hansson [62] found that around 70\% of total fine root biomass lies in the upper $20 \mathrm{~cm}$ of the soil profile. Based on this, annual root biomass input in the $0-20 \mathrm{~cm}$ soil layer was set to $70 \%$ of annual root NPP. For the equivalent green fallow reference case, the root biomass was $60 \%$ of the root NPP in the $0-20 \mathrm{~cm}$ layer [63].

The ICBM model was used to calculate the SOC change in the $0-20 \mathrm{~cm}$ soil layer for the 17-year period. The above-to-below ground accumulation ratio $(\eta)$ was adjusted until the calculated SOC values from the ICBM model matched the measured SOC values from the field trials for all six varieties and treatments. The $\eta$ values obtained by this method are presented in Table 3.

Table 3. Ratio of aboveground to belowground biomass accumulation $(\eta)$ over 3-years for the different Salix varieties and treatments obtained from optimization of the ICBM soil carbon model with field-based soil organic carbon measurements. F0 and F+ refer to the unfertilized and fertilized treatments respectively.

\begin{tabular}{cccccccc}
\hline Parameter & Treatment & Björn & Gudrun & Jorr & Loden & Tora & Tordis \\
\hline \multirow{2}{*}{$\eta$} & F0 & 1.80 & 0.85 & 0.40 & 0.55 & 0.80 & 1.20 \\
& F+ & 8.00 & 1.85 & 1.85 & 2.00 & 2.30 & 3.75 \\
\hline
\end{tabular}

\subsection{Climate Impact}

In the normalized $\mathrm{GWP}_{100}$ metric, the cumulative warming potential of a GHG emission is represented relative to that of $\mathrm{CO}_{2}$ for a 100-year period [64] and expressed in $\mathrm{CO}_{2}$-equivalents. The emissions of $\mathrm{CO}_{2}, \mathrm{CH}_{4}$ and $\mathrm{N}_{2} \mathrm{O}$ are multiplied by their respective characterization factors and summed to arrive at the total GWP 100 . While this is a simplified and popular metric for representation of climate impacts, $\mathrm{GWP}_{100}$ does not capture the effects of timing of the emissions and their absolute impacts on the ecosystem [30,54].

Absolute global temperature change potential (AGTP), also referred to as $\Delta T s$, is a metric that takes into account the timing of emissions and represents the climate impact as a change in temporal global mean surface temperature [65]. Using an absolute metric like AGTP displays the climate impact from a GHG emission as change in temperature $(\Delta T s)$, which approaches the actual physical effect on global temperature but increases uncertainty. This time-dependent LCA methodology, developed by Ericsson et al. [35], was used here as a climate impact indicator in addition to $\mathrm{GWP}_{100}$.

Emission of a GHG at a particular point in time leads to a change in its atmospheric concentration which affects the radiative forcing (RF). This leads to a change in the energy balance on Earth, which results in an increase or decrease in temperature represented as $\Delta T s[35,56]$. GHGs vary in their radiative efficiency and atmospheric residence time, e.g., 
$\mathrm{N}_{2} \mathrm{O}$ and $\mathrm{CH}_{4}$ have atmospheric residence times of 12.1 and 12.4 years, respectively, while $\mathrm{CO}_{2}$ stays in the atmosphere until it is absorbed by the ocean or biosphere [66]. The lifetime of $\mathrm{CO}_{2}$ is modelled based on the Bern carbon cycle. The temperature response of a GHG $\left(\mathrm{AGTP}_{x}\right)$ is defined as:

$$
\operatorname{AGTP}_{x}(H)=\int_{0}^{H} R F_{x}(t) R_{T}(H-t) d t\left(\mathrm{~K} \mathrm{~kg}_{\text {gas }}-1\right)
$$

which represents the complex interaction between radiative forcing $(R F)$ and the temperature response function $\left(R_{T}\right)$ caused by a unit change in RF due to a pulse emission of a GHG ' $x$ ' at a specific time interval $(t)$, and ' $H$ ' is the timeframe of the study. The parameter $R_{T}$ captures the change in temperature due to the change in RF because of emission or uptake of a GHG $(x)$ from the atmosphere at time interval $(t)$. Integrating over the studied period ' $H$ ' gives the temperature response for a particular GHG $\left(\mathrm{AGTP}_{x}\right)$ in terms of $\mathrm{K} \mathrm{kg}_{\text {gas }}{ }^{-1}$. The overall temperature response $(\Delta T s$, measured in $\mathrm{K})$ is the summation of the AGTP of the individual GHG emissions over the study timeframe ' $H$ '. A detailed explanation of the methodology is given in Ericsson et al. [35].

The time-dependent climate impact methodology requires the creation of an inventory of GHG emissions and uptakes distributed over time of the study. Individual temperature responses of each emission are calculated from this inventory. The total system response $(\Delta T s)$ is obtained by summing the individual responses and can be plotted as the change in temperature over time.

\subsection{Sensitivity Analysis}

Even with accurate data collection and standardized methods, uncertainties are unavoidable due to the multiple assumptions and variability involved in modelling and LCA approaches. Sensitivity analysis makes it possible to understand how different factors influence the final results of the analysis [67].

The setting of the system boundary to $20 \mathrm{~cm}$ of soil depth is a source of uncertainty. This is a type of parameter uncertainty and model uncertainty, as change in depth of soil profile changes the system boundaries of the model and related parameters such as SOC values and inputs from BGB. To assess how a greater soil profile would influence the SOC modelling and climate impacts from the different Salix varieties, a one-at-a-time sensitivity analysis was performed. The system boundary was adjusted to include a soil depth of $25 \mathrm{~cm}$ and related parameter of below ground input $\left(i_{b}\right)$ and initial and final SOC values were changed, while other parameters in the analysis remained constant. The average plough depth of $20-25 \mathrm{~cm}$ was the motivation for limiting the soil profile depth, as the subsoil characteristics at the site (both before and after establishment of Salix) were not known.

In soil carbon modelling, the average SOC stock in the $20-25 \mathrm{~cm}$ layer was estimated to be half of the stock in the 10-20 cm layer for each of the varieties described in the previous sections. The root biomass input for Salix and the reference fallow case was $80 \%$ and $65 \%$ of the annual belowground NPP, respectively based on studies of root distribution for Salix [48] and grasses $[63,68]$. The root distribution is subject to variability due to factors such as soil and climate, and hence is a potential source of uncertainty.

\section{Results}

\subsection{Energy Use and Efficiency}

Regarding energy performance, the fertilized treatments of varieties 'Tordis', 'Björn', 'Tora' and 'Jorr' performed best in the ambient conditions, with ERs $\left(\mathrm{GJ}_{\text {out }} \mathrm{GJ}_{\text {in }}{ }^{-1}\right)$ of 28.2 , 26.5, 25.1 and 24.7, respectively (Table 4). Among the unfertilized varieties, 'Tordis' and 'Björn' gave the best energy performance, with ERs of 47.7 and 48.2, respectively. Average

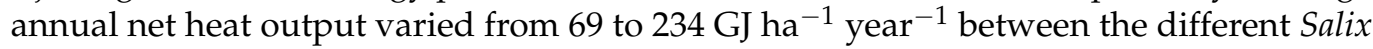
varieties and treatments. Fertilized 'Tordis' had the highest primary energy input of all the varieties as it had the highest yield levels, leading to high biomass and heat output 
(234 GJ ha ${ }^{-1}$ year $^{-1}$ ). Fertilization of 'Gudrun' and 'Loden' did not lead to major improvement in their yield over the unfertilized treatment, which resulted in relatively poor energy performance of the fertilized treatment of these two varieties. Among the unfertilized treatments, the variety 'Björn' had the highest annual heat output, $150 \mathrm{GJ} \mathrm{ha}^{-1}$ year $^{-1}$. The energy output from the heating plant is directly proportional to the biomass yield, which was higher when the plots were fertilized. Hence, the energy outputs in the form of heat were consistently higher for the fertilized treatment compared with the unfertilized treatment. The primary energy input for the fertilized treatment of each variety was about 2.5-4.6 higher than in the equivalent non-fertilized treatment. Consequently, ERs for the unfertilized cases was much higher than in the fertilized cases.

Table 4. Primary energy input, heat output, energy in biomass and energy ratio for the six SRC Salix varieties in fertilized and unfertilized treatments during two rotation periods (years 0-50). F0 and F+ refer to the unfertilized and fertilized treatments, respectively.

\begin{tabular}{|c|c|c|c|c|c|c|c|}
\hline \multirow{2}{*}{$\begin{array}{l}\text { Variety and } \\
\text { Treatment }\end{array}$} & \multicolumn{2}{|c|}{ Energy in Biomass (GJ ha ${ }^{-1}$ ) } & \multicolumn{2}{|c|}{ Primary Energy Input (GJ ha ${ }^{-1}$ ) } & \multicolumn{2}{|c|}{$\begin{array}{l}\text { Net Heat Output } \\
\quad\left(G J h^{-1}\right)\end{array}$} & \multirow{2}{*}{$\begin{array}{l}\text { Energy Ratio } \\
\left(G_{\text {out }} G_{J_{\text {in }}}{ }^{-1}\right)\end{array}$} \\
\hline & Total & $\begin{array}{l}\text { Annual } \\
\text { Average }\end{array}$ & Total & $\begin{array}{l}\text { Annual } \\
\text { Average }\end{array}$ & Total & $\begin{array}{l}\text { Annual } \\
\text { Average }\end{array}$ & \\
\hline Björn F0 & 8245 & 165 & 156 & 3 & 7518 & 150 & 48.2 \\
\hline Björn F+ & 11252 & 225 & 388 & 8 & 10259 & 205 & 26.5 \\
\hline Gudrun F0 & 5525 & 111 & 110 & 2 & 5038 & 101 & 46.0 \\
\hline Gudrun F+ & 5562 & 111 & 290 & 6 & 5071 & 101 & 17.5 \\
\hline Jorr F0 & 3769 & 75 & 79 & 2 & 3437 & 69 & 43.3 \\
\hline Jorr F+ & 9834 & 197 & 364 & 7 & 8967 & 179 & 24.7 \\
\hline Loden F0 & 3757 & 75 & 79 & 2 & 3426 & 69 & 43.2 \\
\hline Loden F+ & 4956 & 99 & 280 & 6 & 4519 & 90 & 16.1 \\
\hline Tora F0 & 4789 & 96 & 97 & 2 & 4366 & 87 & 45.1 \\
\hline Tora F+ & 10177 & 204 & 369 & 7 & 9279 & 186 & 25.1 \\
\hline Tordis F0 & 7526 & 151 & 144 & 3 & 6863 & 137 & 47.7 \\
\hline Tordis F+ & 12859 & 257 & 415 & 8 & 11725 & 234 & 28.2 \\
\hline
\end{tabular}

The contribution of the individual cultivation, transportation and handling processes to the total primary energy input over the study period are described in Table 5. The primary energy associated with pesticides, field preparation, production and planting of seedlings, and stump removal were the same for all six Salix varieties and treatments, as these processes are independent of variety type and fertilization. These are presented on a per hectare basis. The processes of harvesting, chipping, forwarding and transportation are directly proportional to the amount of shoot biomass produced, and hence are presented on basis of per GJ of energy in biomass. Production and spreading of fertilizers were the greatest contributor to primary energy input for fertilized cases, while it was zero for non-fertilized cases.

Table 5. Primary energy inputs by process category associated with the bioenergy system of six Salix varieties in fertilized and unfertilized treatments over the 50-year study period.

\begin{tabular}{|c|c|c|}
\hline Process & Energy (GJ ha $\mathbf{~}^{-1}$ ) & Unit \\
\hline Pesticides ${ }^{a}$ & 4 & $\mathrm{GJ} \mathrm{ha}^{-1}$ \\
\hline Field preparation ${ }^{\mathrm{a}}$ & 6 & GJ ha ${ }^{-1}$ \\
\hline Planting \& seedlings a & 4 & GJ ha ${ }^{-1}$ \\
\hline Stump removal ${ }^{\mathrm{a}}$ & 1 & GJ ha ${ }^{-1}$ \\
\hline Fertilizer ${ }^{b}$ & 0 or 180 & $\mathrm{GJ} \mathrm{ha}^{-1}$ \\
\hline Harvest \& chipping ${ }^{c}$ & $7.33 \times 10^{-3}$ & GJ GJ biomass $^{-1}$ \\
\hline Forwarding (field transport) ${ }^{\mathrm{C}}$ & $3.58 \times 10^{-3}$ & GJ GJ $_{\text {biomass }}{ }^{-1}$ \\
\hline Road transport ${ }^{\mathrm{c}}$ & $6.22 \times 10^{-3}$ & GJ GJ $_{\text {biomass }}-1$ \\
\hline
\end{tabular}

a Processes which are equal for all varieties. ${ }^{b}$ Primary energy associated with fertilization is zero for the unfertilized treatment. ${ }^{c}$ These processes are proportional to the amount of biomass produced in the field. 


\subsection{Soil Organic Carbon}

Soil carbon modelling results showed that all varieties and treatments led to an increase in SOC over the initial level in the topsoil $(0-20 \mathrm{~cm})$ during the study period (50 years) consisting of two rotation periods (Table 6). The SOC stock calculated by the ICBM model at the end of both the first rotation period (after 25 years) and second rotation period (after 50 years) are shown in Table 6. Fertilized 'Loden' and 'Björn' showed the lowest net increase in SOC during the 50-year period, 15.8 and $13.3 \mathrm{Mg} \mathrm{ha}^{-1}$, respectively. These values were only slightly greater than the SOC increase for the fallow reference case (9.5 Mg Cha ${ }^{-1}$ ).

Table 6. Initial, total and net soil organic carbon increase in the $0-20 \mathrm{~cm}$ soil layer after two rotation periods (50 years), as calculated by the ICBM soil carbon model. F0 and F+ refer to the unfertilized and fertilized treatments, respectively.

\begin{tabular}{|c|c|c|c|c|c|c|}
\hline $\begin{array}{l}\text { Variety and } \\
\text { Treatment }\end{array}$ & $\begin{array}{c}\text { Initial SOC } \\
\text { Stock }(0-20 \mathrm{~cm}) \\
\left(\mathrm{Mg} \mathrm{ha}^{-1}\right)\end{array}$ & $\begin{array}{c}\text { SOC Stock } \\
\text { after } 25 \text { Years } \\
(0-20 \mathrm{~cm}) \\
\left(\mathrm{Mg} \mathrm{ha}^{-1}\right)\end{array}$ & $\begin{array}{c}\text { Total SOC } \\
\text { Stock after } 50 \\
\text { Years }(0-20 \mathrm{~cm}) \\
\left(\mathrm{Mg} \mathrm{ha}^{-1}\right)\end{array}$ & $\begin{array}{l}\text { Net SOC } \\
\text { Increase } \\
(0-20 \mathrm{~cm}) \\
\left(\mathrm{Mg} \mathrm{ha}^{-1}\right)\end{array}$ & $\begin{array}{c}\text { Annual SOC } \\
\text { Increase } \\
(0-20 \mathrm{~cm}) \\
\left(\mathrm{Mg} \mathrm{ha}^{-1} \mathrm{yr}^{-1}\right)\end{array}$ & $\begin{array}{l}\text { Change in } \\
\text { SOC after } \\
50 \text { Years }(\%)\end{array}$ \\
\hline Björn F0 & 28.9 & 52.0 & 66.1 & 37.2 & 0.74 & 129 \\
\hline Björn F+ & 28.9 & 37.2 & 42.2 & 13.3 & 0.27 & 46 \\
\hline Gudrun F0 & 28.9 & 60.4 & 79.4 & 50.5 & 1.01 & 175 \\
\hline Gudrun F+ & 28.9 & 42.1 & 49.8 & 20.9 & 0.42 & 73 \\
\hline Jorr F0 & 28.9 & 74.6 & 102.4 & 73.6 & 1.47 & 255 \\
\hline Jorr F+ & 28.9 & 56.7 & 73.7 & 44.9 & 0.90 & 155 \\
\hline Loden F0 & 28.9 & 61.1 & 80.4 & 51.5 & 1.03 & 178 \\
\hline Loden F+ & 28.9 & 38.9 & 44.6 & 15.8 & 0.32 & 55 \\
\hline Tora F0 & 28.9 & 57.3 & 74.3 & 45.5 & 0.91 & 158 \\
\hline Tora F+ & 28.9 & 52.3 & 66.6 & 37.7 & 0.75 & 131 \\
\hline Tordis F0 & 28.9 & 60.4 & 79.6 & 50.7 & 1.01 & 176 \\
\hline Tordis F+ & 28.9 & 48.7 & 60.9 & 32.1 & 0.64 & 111 \\
\hline $\begin{array}{l}\text { Reference- } \\
\text { Fallow }\end{array}$ & 28.9 & 34.3 & 38.4 & 9.5 & 0.19 & 33 \\
\hline
\end{tabular}

The carbon modelling results also showed that the unfertilized treatment for each variety was able to sequester about 1.6 to 3.3 times more SOC than the fertilized case, except for 'Tora'. Both treatments of 'Tora' led to a similar increase in SOC stock in the topsoil.

The low-yielding variety 'Jorr' showed the greatest potential for net carbon sequestration, capturing $73.6 \mathrm{MgC} \mathrm{ha}^{-1}$ and $44.9 \mathrm{MgC} \mathrm{ha}^{-1}$ over 50 years in the unfertilized and fertilized treatments, respectively. The variety 'Gudrun' had similar biomass yields for both the fertilized and unfertilized treatments (Table 1), but net SOC increase in the unfertilized case was almost double that in the fertilized case. 'Björn' had high biomass yields, but the SOC increase was at the lower end of the spectrum. Thus, no clear correlation between biomass yield and net SOC increase was established. These results indicate that the impacts on SOC are variety-specific, and that fertilization in general leads to lower net SOC increase.

\subsection{Time-Dependent Climate Impact}

\subsubsection{Impact Per Hectare of Land (Including Substitution Effects)}

All Salix varieties and treatments gave a negative temperature response $(\Delta T s)$ over the study period, which equated to a lowering of the global mean temperature when substituting reference fossil energy (natural gas) and reference land use (fallow) (Figure 2). There was great variation in temperature response between the varieties, from $-2.15 \times 10^{-10} \mathrm{~K} \mathrm{ha}^{-1}$ for fertilized 'Loden' to $-5.99 \times 10^{-10} \mathrm{~K} \mathrm{ha}^{-1}$ for fertilized 'Tordis'. Fertilized 'Tordis', 'Björn', 'Tora' and 'Jorr' had the greatest negative $\Delta$ Ts per hectare of land, which is explained by the high levels of yield combined with an increase in SOC stocks. These cases represent the best use of land area under the study conditions for climate change mitigation. 


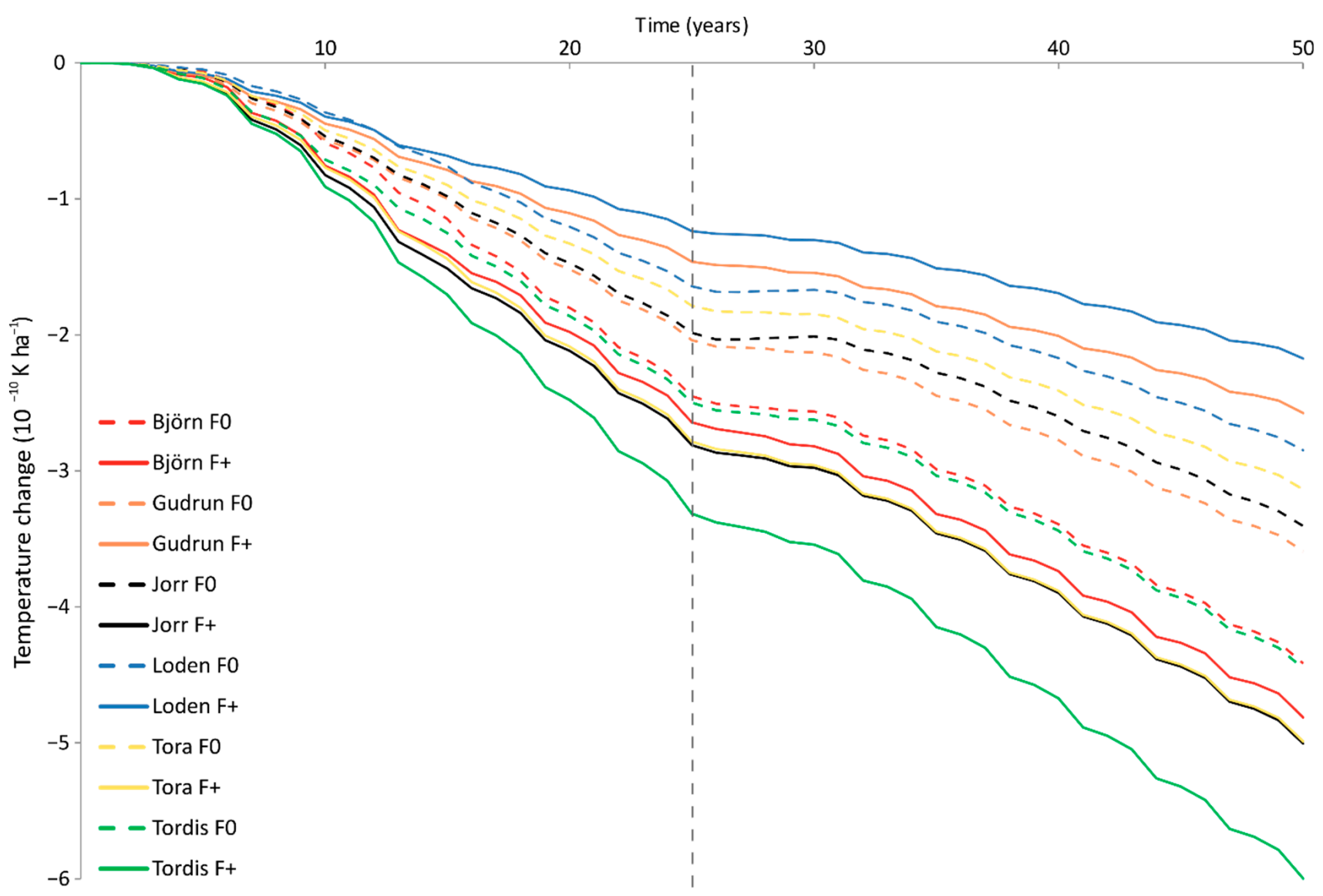

Figure 2. Time-dependent temperature response of the Salix SRC systems with substitution effects included. The vertical dashed line represents the end of the first rotation and start of the second (at 25 years). F0 and F+ refer to the unfertilized and fertilized treatments, respectively.

Although the unfertilized treatment of each variety had greater $\mathrm{CO}_{2}$ sequestration potential, the increase in biomass output achieved by fertilization led to higher replacement of fossil energy. As a result, fertilized cases had lower $\Delta T s$ values. 'Loden' and 'Gudrun' were exceptions, as their fertilized cases showed a greater temperature response than the unfertilized cases. These two varieties gained little to no improvement in their yield from fertilization, so the additional energy and material input through fertilization led to a lower climate mitigation potential.

\subsubsection{Impact Per Unit of Heat Output (Including Substitution Effects)}

A different picture emerges when the climate impacts from all cases were expressed based on their function of delivering energy services (per $\mathrm{MJ}_{\text {heat }}$ ) and replacing fossilgenerated heat (Figure 3). Unfertilized 'Jorr' showed the greatest climate mitigation effect $\left(-5.11 \times 10^{-15} \mathrm{~K} \mathrm{MJ}^{-1}\right)$, while fertilized 'Björn' $\left(-2.39 \times 10^{-15} \mathrm{~K} \mathrm{MJ}^{-1}\right)$ had the lowest. The non-fertilized varieties showed a greater negative temperature response (per $\mathrm{MJ}_{\text {heat }}$ ) than the fertilized varieties. This can be attributed to the higher primary energy demand for the fertilized treatments, combined with the greater SOC increase for the unfertilized cases.

The unfertilized cases were more favorable for climate change mitigation on comparing when the climate impacts per unit of energy delivered $\left(\mathrm{MJ}_{\text {heat }}\right)$ by the biomass systems. This is relevant when comparing energy generation systems and land is not a restricted resource. Unfertilized 'Jorr' and 'Loden' were the best-performing varieties in terms of potential for temperature reduction per unit of energy, although they had the lowest biomass yield. Fertilized 'Loden', 'Gudrun' and 'Björn' had the lowest temperature decrease $\left(\Delta T\right.$ s per $\mathrm{MJ}_{\text {heat }}$ ) over the study period. Those cases also had the lowest SOC increase over the study period. 


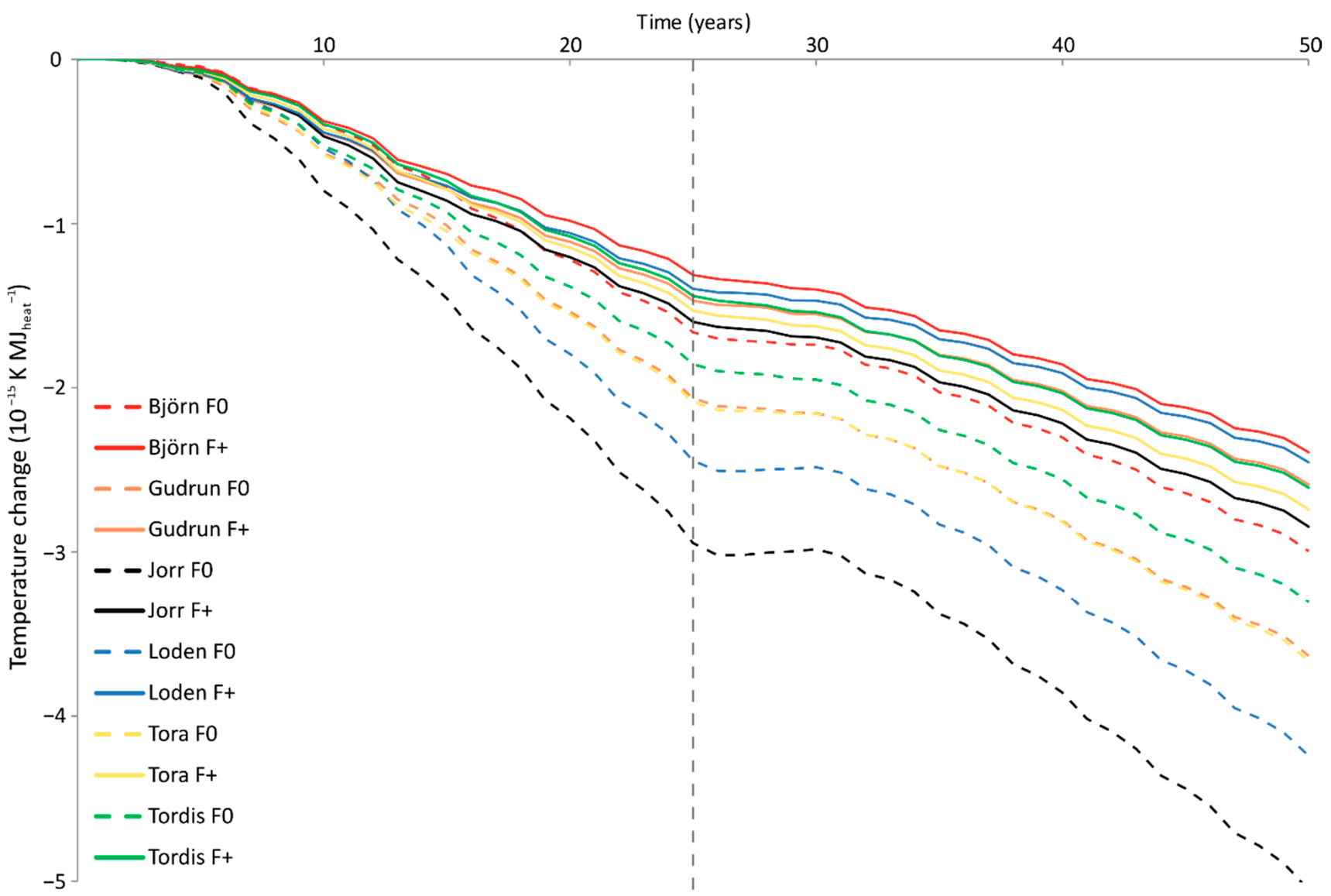

Figure 3. Temperature response per MJ of heat for the Salix SRC systems, with substitution effects included. The vertical dashed line represents the end of the first rotation and start of the second (at 25 years). F0 and F+ refer to the unfertilized and fertilized treatments, respectively.

\subsection{Global Warming Potential}

The life cycle impact assessment of the different varieties under the two fertilization regimes showed varying climate impacts. A negative value of the $\mathrm{GWP}_{100}$ metric means that there is a net reduction of atmospheric GHG concentration, leading to a climate mitigation effect. In absolute terms (not including the effect of substituting the reference case), unfertilized 'Jorr' had the lowest $\mathrm{GWP}_{100}\left(-333 \mathrm{Mg} \mathrm{CO}_{2}\right.$-eq. ha $\left.{ }^{-1}\right)$, while fertilized 'Björn' had the highest total GWP 100 (30 Mg CO ${ }_{2}$-eq. ha ${ }^{-1}$ ) (Table 7).

Among the fertilized varieties, 'Björn' and 'Loden' were the worst performing in terms of climate mitigation effects per hectare over 50 years. These varieties had the lowest increase in SOC among the fertilized varieties, which contributed to their poorer climate performance. Fertilized 'Tora' and 'Jorr', which had the highest increase in SOC among fertilized varieties, showed the greatest reduction in GWP, indicating the importance of soil carbon sequestration for achieving a climate change-mitigating effect.

Considering the effects of substitution of a natural gas-based reference system for the SRC Salix, all varieties showed a climate-mitigating effect during the study period. The magnitude of the mitigation effect ranged from $-312 \mathrm{Mg} \mathrm{CO}_{2}$-eq.ha ${ }^{-1}$ for fertilized 'Loden' to $-858 \mathrm{Mg} \mathrm{CO}_{2}$-eq. ha ${ }^{-1}$ for fertilized 'Tordis'. On considering the substitution effects, the yield level influenced GWP. High yields contributed to a greater climate mitigation effect, as seen for fertilized 'Tordis', 'Björn', 'Jorr' and 'Tora'. This is a result of avoided equivalent emissions from heat produced in the fossil reference system. 
Table 7. Global warming potential $\left(\mathrm{GWP}_{100}\right)$ for the Salix cropping systems and fossil-powered reference system and effect of substitution when Salix was assumed to replace the reference system. The GWP is expressed in both $\mathrm{Mg} \mathrm{CO}_{2}$-eq per hectare and $\mathrm{g} \mathrm{CO}_{2}$-eq per MJ of heat during the 50-year study period. F0 and F+ refer to the unfertilized and fertilized treatments, respectively. A positive value indicates emissions to atmosphere, and a negative value indicates reduction.

\begin{tabular}{|c|c|c|c|c|c|c|}
\hline \multirow{3}{*}{$\begin{array}{l}\text { Variety and } \\
\text { Treatment }\end{array}$} & \multicolumn{6}{|c|}{ Global Warming Potential $\left(\mathrm{GWP}_{100}\right)$} \\
\hline & \multicolumn{2}{|c|}{ SRC System ${ }^{a}$} & \multicolumn{2}{|c|}{ Reference System ${ }^{\mathbf{b}}$} & \multicolumn{2}{|c|}{ Substitution Effect ${ }^{c}$} \\
\hline & $\operatorname{Mg~ha}^{-1}$ & $\mathrm{~g} \mathrm{MJ}^{-1}$ & $\operatorname{Mg~ha}^{-1}$ & $\mathrm{~g} \mathrm{MJ}^{-1}$ & $\operatorname{Mg~ha}^{-1}$ & $\mathrm{~g} \mathrm{MJ}^{-1}$ \\
\hline Björn F0 & -143 & -19 & 514 & 68 & -657 & -87 \\
\hline Björn F+ & 30 & 3 & 707 & 94 & -677 & -91 \\
\hline Gudrun F0 & -220 & -44 & 339 & 67 & -558 & -111 \\
\hline Gudrun F+ & -31 & -6 & 340 & 68 & -372 & -74 \\
\hline Jorr F0 & -333 & -97 & 225 & 65 & -558 & -162 \\
\hline Jorr F+ & -114 & -13 & 616 & 179 & -730 & -192 \\
\hline Loden F0 & -231 & -68 & 225 & 66 & -456 & -133 \\
\hline Loden F+ & -10 & -2 & 301 & 88 & -312 & -90 \\
\hline Tora F0 & -198 & -45 & 291 & 67 & -489 & -112 \\
\hline Tora F+ & -84 & -9 & 638 & 146 & -722 & -155 \\
\hline Tordis F0 & -210 & -31 & 467 & 68 & -678 & -99 \\
\hline Tordis F+ & -47 & -4 & 811 & 118 & -858 & -122 \\
\hline
\end{tabular}

${ }^{\mathrm{a}}$ Climate impact of SRC Salix system without substitution effect. ${ }^{\mathrm{b}}$ Climate impact of reference system-heat from natural gas and green fallow land use. ${ }^{c}$ Climate impact of SRC Salix system including substitution effects of reference system.

From the perspective of heat delivered with substitution effects, fertilized 'Jorr' had the highest climate mitigation effect, $-192 \mathrm{~g} \mathrm{CO}_{2}$-eq.MJ $\mathrm{Meat}^{-1}$ produced, while fertilized 'Gudrun' was at the other end of the spectrum, with $-74 \mathrm{~g} \mathrm{CO}_{2}$-eq.MJ $\mathrm{M}_{\text {heat }}{ }^{-1}$ produced.

The contribution of the Salix production chain emissions, SOC sequestration and substitution effects to the overall net $\mathrm{GWP}_{100}$ per hectare for the different Salix varieties are presented in Figure 4. The production chain leads to GHG emissions while SOC sequestration and substitution effects remove or replace GHG emissions. Emissions from the production chain (field operations, transportation, fertilizer and soil emissions) are higher for fertilized varieties due to fertilizer production and greater soil $\mathrm{N}_{2} \mathrm{O}$ emissions. The substitution effects are the main contributor to the overall negative $\mathrm{GWP}_{100}$ for all Salix varieties, except for unfertilized Loden and Jorr. These two varieties showed a greater potential of SOC sequestration relative to harvest yields in comparison to the other Salix varieties. Alternatively fertilized Gudrun and Loden have a higher $\mathrm{GWP}_{100}$ compared to their unfertilized counterparts due to relatively lower improvement in yield.

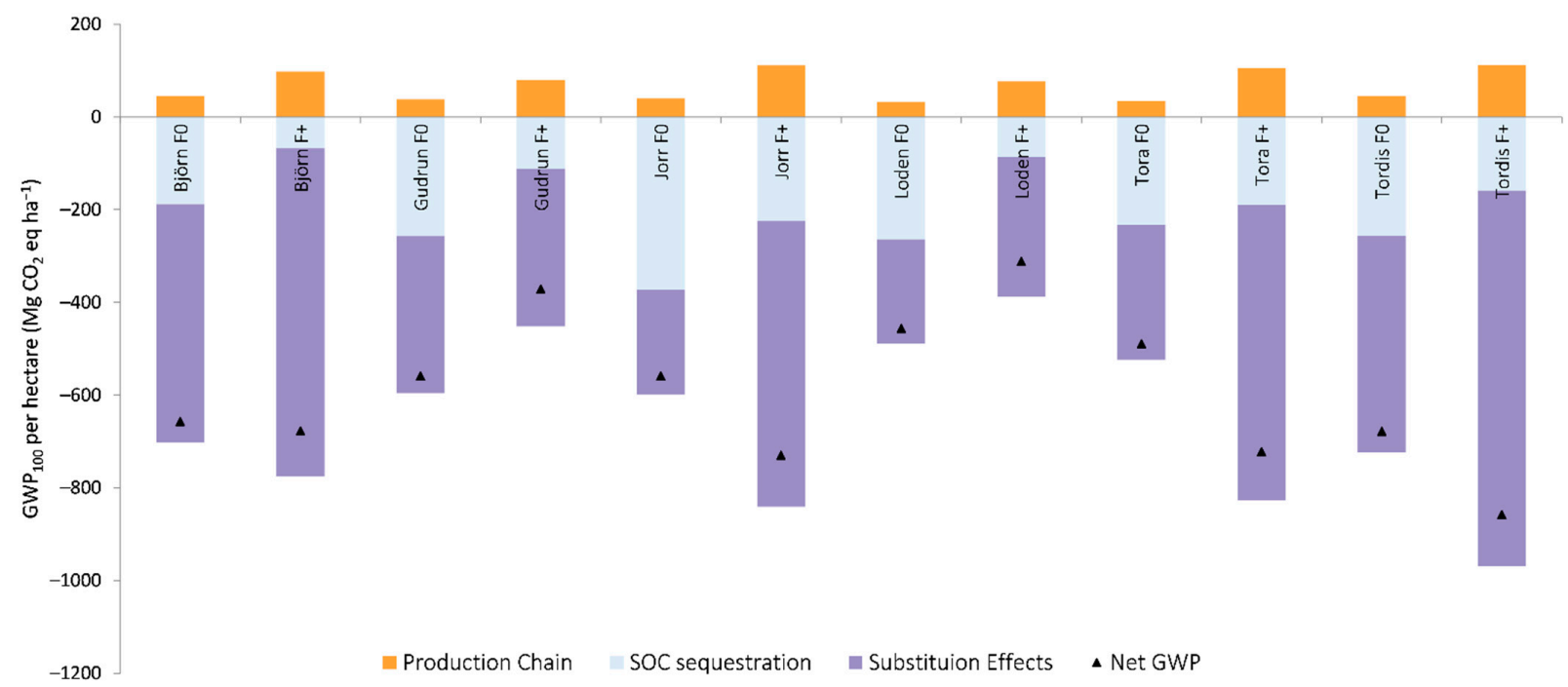

Figure 4. Contribution of the Salix production chain, SOC sequestration, substitution effects (from replacing green fallow and fossil energy) to the net $\mathrm{GWP}_{100}$ per hectare of each of the Salix bioenergy system. 


\subsection{Sensitivity Analysis}

The sensitivity analysis results for net SOC increase and climate impacts $\left(\mathrm{GWP}_{100}\right)$ from considering a soil depth of $25 \mathrm{~cm}$, compared with the base case of $20 \mathrm{~cm}$, are shown in Table 8. Generally, a deeper soil layer gave a greater net SOC increase within the system boundary, leading to a lower climate impact. Fertilized 'Björn', 'Gudrun' and 'Loden' were exceptions to this, as the net SOC increase in the $0-25 \mathrm{~cm}$ layer was smaller than in the 0-20 cm layer. Consequently, the climate impacts for these three cases were also greater.

Table 8. Sensitivity analysis of soil organic carbon (SOC) sequestration and global warming potential $\left(\mathrm{GWP}_{100}\right)$ for the six Salix varieties in the fertilized and unfertilized treatments, when soil depth considered was increased from 20 to $25 \mathrm{~cm}$. F0 and F+ refer to the unfertilized and fertilized treatments, respectively.

\begin{tabular}{|c|c|c|c|c|c|c|c|c|}
\hline \multirow{3}{*}{$\begin{array}{l}\text { Variety and } \\
\text { Treatment }\end{array}$} & \multicolumn{4}{|c|}{ 0-20 cm Soil Layer } & \multicolumn{4}{|c|}{ 0-25 cm Soil Layer } \\
\hline & $\begin{array}{l}\text { Net SOC } \\
\text { Increase }\end{array}$ & $\begin{array}{c}\text { Annual SOC } \\
\text { Uptake }\end{array}$ & $\mathbf{G W P}_{100}$ & $\mathrm{GWP}_{100}$ & $\begin{array}{l}\text { Net SOC } \\
\text { Increase }\end{array}$ & $\begin{array}{c}\text { Annual SOC } \\
\text { Uptake }\end{array}$ & $\mathbf{G W P}_{100}$ & $\mathrm{GWP}_{100}$ \\
\hline & $\left(\mathrm{Mg} \mathrm{ha}^{-1}\right)$ & $\left(\mathrm{Mg} \mathrm{ha}^{-1} \mathrm{yr}^{-1}\right)$ & $\left(\mathrm{Mg} \mathrm{ha}^{-1}\right)$ & $\left(\mathrm{g} \mathrm{MJ}^{-1}\right)$ & $\left(\mathrm{Mg} \mathrm{ha}^{-1}\right)$ & $\left(\mathrm{Mg} \mathrm{ha}^{-1} \mathrm{yr}^{-1}\right)$ & $\left(\mathrm{Mg} \mathrm{ha}^{-1}\right)$ & $\left(\mathrm{g} \mathrm{MJ}^{-1}\right)$ \\
\hline Björn F0 & 37.2 & 0.74 & -143 & -19 & 40.1 & 0.80 & -100 & -13 \\
\hline Björn F+ & 13.3 & 0.27 & 30 & 3 & 10.8 & 0.22 & 58 & 6 \\
\hline Gudrun F0 & 50.5 & 1.01 & -220 & -44 & 64.1 & 1.28 & -193 & -38 \\
\hline Gudrun F+ & 20.9 & 0.42 & -31 & -6 & 19.7 & 0.39 & 9 & 2 \\
\hline Jorr F0 & 73.6 & 1.47 & -333 & -97 & 82.0 & 1.64 & -258 & -75 \\
\hline Jorr F+ & 44.9 & 0.90 & -114 & -13 & 45.7 & 0.91 & -55 & -6 \\
\hline Loden F0 & 51.5 & 1.03 & -231 & -68 & 57.1 & 1.14 & -175 & -51 \\
\hline Loden F+ & 15.8 & 0.32 & -10 & -2 & 13.9 & 0.28 & 26 & 6 \\
\hline Tora F0 & 45.5 & 0.91 & -198 & -45 & 50.1 & 1.00 & -147 & -34 \\
\hline Tora F+ & 37.7 & 0.75 & -84 & -9 & 50.1 & 1.00 & -34 & -4 \\
\hline Tordis F0 & 50.7 & 1.01 & -210 & -31 & 58.2 & 1.16 & -165 & -24 \\
\hline Tordis F+ & 32.1 & 0.64 & -47 & -4 & 33.6 & 0.67 & -9 & -1 \\
\hline
\end{tabular}

Fertilized 'Björn', 'Gudrun' and 'Loden' showed the lowest SOC increase in field measurements from 2001-2018, which led to lower SOC sequestration rates. On considering a deeper soil layer, the starting SOC level prior to Salix establishment was also higher. In absolute terms, the final SOC stock was greater with a deeper soil layer, but the net increase was lower for these three cases when compared with a shallower $(20 \mathrm{~cm})$ layer. Thus, a lower sequestration rate combined with a greater initial SOC level led to a smaller SOC increase for these fertilized varieties with increased soil depth. Overall, the changes in SOC stock and climate impacts were not highly influenced by considering a deeper soil layer of $25 \mathrm{~cm}$.

\section{Discussion}

The analysis revealed that cultivation of the selected Salix varieties for bioenergy to substitute equivalent fossil fuels (under the given environmental and site conditions) can potentially mitigate climate change as it has a net cooling effect on global mean surface temperature over a 50-year time horizon. Salix variety had a major influence on the climate change mitigation potential. The Salix varieties in this study varied in some key factors derived from measured field data (SOC sequestration, biomass yield and response to fertilization) and these factors affected the overall climate impact between the different varieties. The major contribution to the climate mitigation effect comes from substitution of fossil fuels and SOC sequestration. While fossil fuel replacement is relatively easy to estimate using harvest yields, estimation of SOC change over time is complicated as it is subject to various environmental conditions and uncertainties.

The flue gas condensation technology assumed in the incineration plant with heat recovery gives high energy efficiency, leading to a greater output of energy delivered which puts the energy ratio in the higher range. This is a common technology in Swedish power plants [64], although it might not be common in other countries. The conversion efficiency 
of the thermochemical processes selected in a study determines the amount of useful energy production from the system and its subsequent ER. The ER in this study was within the range 16.1-28.2 for fertilized Salix varieties and 43.2-48.2 for non-fertilized varieties. Values of ER reported in the literature range from 16 to 79 in energy performance analysis studies [69-76], which are indicative of different methods and assumptions considered in individual studies.

The results in the present study indicate that Salix variety and fertilization regime strongly affect the NPP distribution between aboveground and belowground biomass. The ratio of NPP of annual aboveground biomass (AGB) to belowground biomass (BGB) in our study was estimated at $0.4-1.8$ for unfertilized treatments and 1.9-8.0 for fertilized treatments (Table 3). The estimation of these values is based on the well-established conception that variety and fertilization influence the production of BGB relative to AGB, which leads to variation in SOC change.

Data on AGB and BGB production and allocation for Salix from some studies are presented in Table 9. Heinsoo et al. [77] reported large differences in the magnitude of the ratio between AGB and fine root production for fertilized and control plots in an Estonian Salix plantation with two species (S. viminalis and S. dasyclados). This study reported a significant reduction in annual production of fine root biomass under fertilization, while AGB production was greatly improved. The AGB to BGB production ratio for $S$. viminalis was 1.04-2.07 for lysimeter-grown Salix in sandy and clayey soils [61]. Rytter [78] found significant differences in biomass allocation to fine-roots between N-limited and unlimited growing conditions (for S. viminalis) but no change in annual turnover rates of fine roots. These studies support the idea that fertilization can lead to lower BGB production that leads to very different AGB to BGB ratios between unfertilized and fertilized treatments.

Table 9. Aboveground to Belowground biomass production and allocation ratios of Salix varieties reported under different environmental conditions.

\begin{tabular}{|c|c|c|}
\hline Study & Description & Value \\
\hline \multirow{5}{*}{ Heinsoo et al., 2009 [77] } & Ratio of aboveground to fine root annual production & \\
\hline & S. viminalis control & $1.16-1.09$ \\
\hline & S. viminalis fertilized & $14.28-12.5$ \\
\hline & S. dasyclados control & $2.85-1.51$ \\
\hline & S. dasyclados fertilized & $20-16.67$ \\
\hline \multirow{4}{*}{ Rytter, 2001 [61] } & $\begin{array}{l}\text { Ratio of total aboveground to belowground production } \\
\text { of } S \text {. viminalis } L\end{array}$ & \\
\hline & Year 1 & $1.04-0.73$ \\
\hline & Year 2 & $1.73-2.07$ \\
\hline & Year 3 & $1.63-1.5$ \\
\hline \multirow{3}{*}{ Rytter, 2013 [78] } & $\begin{array}{c}\text { Ratio of annual production of stem to fine root of } \\
\text { S. viminalis } L\end{array}$ & \\
\hline & N limited & 0.65 \\
\hline & Unlimited & 1.84 \\
\hline Pacaldo et al., 2013 [79] & $\begin{array}{l}\text { Ratio of biomass allocation of Aboveground biomass } \\
\text { (Stem + Leaf) to Belowground biomass (FR + CR + stool) } \\
\text { of S. dasyclados }\end{array}$ & $0.32-0.61$ \\
\hline
\end{tabular}

Pacaldo et al. [79] reported biomass allocation for a single Salix variety (S. dasyclados) from two locations with different plantation ages and soil conditions; based on their data, the AGB to BGB allocation ratio was 0.32-0.61. The ratio of annual production of AGB to BGB in our study falls within the range of values reported for Salix in different studies, but these figures need to be validated by further studies on belowground biomass to increase accuracy in soil carbon modelling estimates. 
Salix roots are characterized by high growth and mortality rates [80] and are not bound by seasonal patterns, with some growth and decay observed even during winter [61]. This indicates that root production is relatively higher under a non-fertilized regime, which combined with unchanged turnover rates would lead to higher belowground biomass input to the soil compared with a fertilized treatment, which can lead to greater SOC stocks.

The few previous studies on how biomass growth and allocation differ between Salix varieties $[43,81,82]$ have shown that variety and growing environment can have significant impacts on biomass allocation and growth patterns. Cunniff et al. [43] found that belowground allocation differed up to $10 \%$ between Salix varieties and up to $94 \%$ between locations. Furthermore, a study by Gregory et al. [81] found significant differences in root density between Salix varieties, especially in the upper layers.

There is a scarcity of data on belowground biomass allocation and its variation between Salix varieties and environmental conditions. Only a few studies measured the production and turnover of roots (especially fine roots) as these analyses are time-consuming, laborintensive and expensive [83]. Furthermore, the estimation of root growth and number can greatly vary due to the measurement method used [84]. A study including two Salix varieties [85] has also shown differences in decomposition rates of fine root litters, which further stresses the need for variety focused studies. This makes it difficult and complicated to compare data on aboveground to belowground biomass accumulation from different sources, as variations can occur owing to multiple factors. This is a source of variability in determining especially belowground biomass growth and its contribution to SOC sequestration. There is need for further research and standardization of methods to enable comparisons and calibration of soil carbon models to make more reliable long-term predictions.

In spite of the uncertainties regarding the variety-related input variables for soil carbon modelling, this investigation provides useful insights into the expected variety-related SOC changes over a longer period of time and based on measured data of above ground biomass and soil SOC over an 18-year period. While these uncertainties might affect all investigated varieties in a similar way, they are likely to result mostly in an uncertain absolute magnitude of SOC after a certain period of time, whereas the variety-specific pattern of SOC change is expected to be more robust. Thus, we believe that the use of Salix variety-specific data from the field study in this analysis is a clear improvement over previous studies dealing with SOC modelling in Salix. The scaling and extrapolation of soil carbon models is a challenge due to lack of long-term data and the complexity of SOC sequestration mechanisms. Despite the challenges, such approaches with assumed data are a necessary part of making sustainable management decisions. The accuracy of the models and their predictions can be constantly adjusted by feedback of new measured data and advancing knowledge of SOC.

The carbon modelling based on measured SOC levels from the measured field trial data, showed that non-fertilization led to a greater increase in SOC compared with fertilization of the same variety under the same soil conditions. A relationship between shoot biomass yield and increase in SOC was expected from other studies, but was not seen in our study, as greater yield did not correlate with more $\mathrm{CO}_{2}$ being sequestered in the soil. For example, unfertilized 'Jorr' had one of the lowest shoot biomass yields among all varieties investigated here, but showed the highest increase in SOC in the top $20 \mathrm{~cm}$ soil layer; while fertilized 'Björn', with high biomass output, had one of the lowest increases in SOC stocks. This result questions the common assumption of higher shoot biomass yield leading to a greater increase in SOC due to higher production of leaf and root litter. While greater shoot biomass may lead to increased leaf litter production, root litter production might show a differential pattern. Interestingly, Pappas et al. [86] found that in boreal forests, aboveground biomass growth is decoupled from the carbon input to the ecosystem, highlighting the significance of belowground carbon inputs independent from aboveground growth. Also, Khan et al. [87] conclude that N-fertilization increases harvests for crops but can have a negative effect on SOC sequestration. 
The SOC accumulation rate in our study was $0.24-1.29 \mathrm{Mg} \mathrm{ha}^{-1} \mathrm{yr}^{-1}$ for the 0-20 cm soil layer over 50 years. Direct comparisons of SOC changes reported in different studies are difficult, because of variations in initial soil conditions, study period, growing conditions, methodology and depth of soil profile considered in the study. The test site had a clay content of $18 \%$. This clay content promotes long-term carbon sequestration by stabilization of SOC against decomposition [88]. SOC sequestration rates of 1.44-2.27 $\mathrm{Mg} \mathrm{ha}^{-1} \mathrm{yr}^{-1}$ for the top $30 \mathrm{~cm}$ soil layer have been reported for two Salix varieties during a 6-year study period in the UK [81]. Other recent studies have recorded SOC sequestration rates of $1 \mathrm{Mg} \mathrm{ha}^{-1} \mathrm{yr}^{-1}$ in the upper $10 \mathrm{~cm}$ in Italy [89] and high levels of $6.7-10.2 \mathrm{Mg} \mathrm{ha}^{-1} \mathrm{yr}^{-1} \mathrm{in}$ the upper $60 \mathrm{~cm}$ in Belgium [90]. In a meta-analysis by Agostini et al. [18], SOC accumulation rates in the range -0.06 to $3.57 \mathrm{Mg} \mathrm{ha}^{-1} \mathrm{yr}^{-1} \mathrm{Mg} \mathrm{ha}^{-1} \mathrm{yr}^{-1}$ were found for Salix. However, the studies in the meta-analysis varied greatly in methodology, soil conditions and length of study period, impeding comparisons. Greater accumulation rates have been reported for Salix grown on former arable land compared with grassland [91]. The amount and rate of SOC change are highly dependent on the previous land use, which consequently plays a major role in the climate impact. In any case, the annual SOC accumulation rates in our study clearly fall within the range reported from other sources. However, there is a need for further investigation of root production, turnover and decay based on soil types, plant variety, and nutrient regimes because the soil carbon change has an important effect in determining the climate impacts and should therefore be included in systems studies

From a land use perspective, the climate impact was governed by the Salix biomass yield. Higher biomass yields contributed to a greater replacement of fossil energy, thereby contributing to a greater cooling effect. Exceptions to this were the varieties 'Gudrun' and 'Loden', which showed almost no improvement in yield from fertilization. Thus, for optimum climate mitigation per unit land area, a high-yielding variety needs to be selected. However, on comparing the varieties from the functional unit of energy output (per MJ of energy output), the SOC sequestration potential played the major role in determining the climate impact. In this regard, the unfertilized varieties with good yields and SOC sequestration potential offered greater potential cooling effects. Hence the basis of comparison (land use or energy output) also plays an important role in the interpretation of climate impact results.

A literature review by Djomo et al. [54] reported that LCAs of short-rotation bioenergy crops often use very different system boundaries, impact indicators and conditions, which makes comparisons between studies difficult. All scenarios analyzed in the present study showed a GWP reduction potential of 95 to $237 \%$ compared with the fossil reference system (Table 7). This is much higher than the 90-99\% reduction potential presented in the review by Djomo et al. [54], but only one study in that review had considered the effects of soil carbon sequestration. The high yield levels for unfertilized Salix varieties in the present study, combined with SOC sequestration, explain the much higher GWP reduction potential estimated in our study. However, the soil is not an endless $C$ sink and increasing temperatures under climate change will accelerate the degradation of SOC, thereby reducing the size of the sink. Thus, the SOC sequestration potential is expected to decrease over time because of climate change. It is difficult to predict technological change during a long period, so in this study the systems were assumed to remain static during the 50-year period. Assuming a constant level of cultivation of Salix at the same location, the cooling effect from an increasing SOC pool will eventually decline, but the warming effect due to GHG emissions from the production system will continue to increase over time. The major sources of emissions are production of fertilizers and $\mathrm{N}_{2} \mathrm{O}$ soil emissions. From a longer time perspective, these emissions will be of uppermost importance in improving the climate performance of Salix production systems.

Default IPCC values for calculation of nitrogen leaching from mineral fertilizers were used in this study, due to lack of site-specific data. Salix has been shown to have lower nitrogen leaching rates than other crops [40,92], and thus the default values used here might be on the higher side for Salix cultivation. In the field trials, all fertilized plots were 
enriched with the same quantity of mineral fertilizer, which might be higher or lower than the optimal fertilization level of the plant. Fertilization studies can help to determine the optimum fertilization by variety, which will greatly influence the emissions and energy input of the fertilization phase and the AGB to BGB production ratio.

The scarcity of complete data that are site- and variety-specific for all aspects of the Salix bioenergy production and decomposition poses some limitations. The SOC changes and climate impacts from one study should not be directly extrapolated to other cases as there are several factors (such as environmental conditions and previous land use) which can lead to different results. The results of this study stress the importance of accounting for variety and fertilization effects when estimating SOC changes and climate impacts of Salix bioenergy systems. As such, these effects should not be ignored in planning for bioenergy systems of the future. There is potential to develop varieties with high levels of both shoot and root biomass with efficient fertilizer utilization, which would give a greater climate mitigation benefit.

\section{Conclusions}

Soil carbon modelling based on Swedish field trial data showed that all Salix varieties tested can potentially increase the SOC stock in the soil over a period of 50 years under given soil conditions of vertic cambisols. Salix variety and fertilization treatment determined the magnitude of $\mathrm{CO}_{2}$ sequestration. No clear relationship was found between biomass yield and SOC sequestration potential across the varieties and soil type used in this study, which indicates that belowground biomass accumulation and decomposition should not be directly estimated from shoot yield alone. High production and turnover rate of fine roots was estimated to be the major contributor to SOC inputs by Salix. Fertilization led to an increase in biomass yield (and therefore energy output), but a decrease in SOC sequestration potential, across all varieties.

The fertilized 'Björn' biomass systems showed a warming effect on the climate (positive GWP) without inclusion of substitution effects from replacing a natural gas-based reference case. However, all varieties and treatments showed the potential to mitigate climate change (negative GWP and $\Delta T s$ ) on inclusion of substitution effects. High-yielding Salix varieties had the greatest potential to mitigate climate change when looking from a land-use perspective. When comparing per energy unit, the SOC sequestration effects become more prominent in determining the overall magnitude of the climate change mitigation potential of the different Salix varieties. System analysis approaches like LCA should incorporate SOC effects, which can significantly affect the climate impacts of biomass cultivation systems, as seen here for six Salix varieties.

Initial soil conditions are very important for biomass productivity because they influence the amount of leaf and root litter produced, which in turn influence the SOC accumulation rate. Hence, previous land use needs careful consideration when evaluating climate impacts. Results in previous studies, combined with our findings, show that there is some uncertainty about SOC sequestration rates, which makes it important to research belowground biomass production, including varietal and location effects.

The results from this study highlight the effects of variety on SOC sequestration, biomass yield, response to fertilization and, ultimately, climate impact. This shows the importance of selecting the appropriate variety of Salix and management practices based on the desired outcome from the bioenergy system.

Supplementary Materials: The following are available online at https:/ / www.mdpi.com/article / 10.3390/f12111529/s1, Table S1: Parameters used to model SOC changes in ICBM. Table S2: Initial values of aboveground $\left(\mathrm{Y}_{\mathrm{a}}\right)$ and belowground $\left(\mathrm{Y}_{\mathrm{b}}\right)$ young pool, and old pool $(\mathrm{O})$ used in the ICBM calculation. Table S3: Values used to calculate the biomass allocation between the different pools (stems, leaves, fine roots and coarse roots) at stages of growth as a percentage of their 3-year net primary production. Table S4: The nitrogen content in leaf litter was calculated according to the abscission leaf $\mathrm{N}$ content by variety and fertilization as reported by Weih and Nordh, 2002. Table S5: The nitrogen $(\mathrm{N})$ content of roots was calculated from the dataset by Manzoni et al., 2021. Table S6: 
Energy input and emissions associated with production of pesticides, cutting, fertilizer and fossil fuels. Table S7: Data used to estimate emissions and energy usage for operations in the biomass procurement chain. Table S8: Data used to model emissions and energy for the reference case.

Author Contributions: Conceptualization, S.K., H.K.P., M.W., C.B., Å.N. and P.-A.H.; methodology, S.K.; formal analysis, S.K.; investigation, C.B.; data curation, M.W. and C.B.; writing-original draft preparation, S.K.; writing-review and editing, S.K., H.K.P., M.W., C.B., Å.N. and P.-A.H.; supervision, P.-A.H. and M.W. All authors have read and agreed to the published version of the manuscript.

Funding: This research received funding from Formas (The Swedish Research Council for Environment, Agricultural sciences and Spatial Planning) for the OPTUS and MixForChange projects under grants no 942-2016-31 and 2020-02339. Part of the soil analyses was funded by Deutsche Forschungsgesellschaft (DFG), project no. BA 1494/9-1.

Institutional Review Board Statement: Not applicable.

Informed Consent Statement: Not applicable.

Data Availability Statement: The data presented in this study are available the supplementary material and within the article. If required, further relevant details are available from the corresponding author on request.

Acknowledgments: We are grateful to Niclas Ericsson and Torun Hammar for their work on soil carbon modelling and climate impacts of Salix, and their help in adapting those methods for this study.

Conflicts of Interest: The authors declare no conflict of interest.

\section{Appendix A}

Table A1. Default parameters used in Equations (2) and (3) to calculate $\mathrm{N}_{2} \mathrm{O}$ emissions as described in IPCC 2019 [56].

\begin{tabular}{|c|c|c|c|}
\hline Parameter & Description & Value & Unit \\
\hline $\mathrm{EF}_{\mathrm{N}}$ & Direct emissions from applied N & 0.01 & $\mathrm{~kg} \mathrm{~N}_{2} \mathrm{O}-\mathrm{N} \mathrm{kg}^{-1} \mathrm{~N}$ \\
\hline $\mathrm{EF}_{\mathrm{D}}$ & $\begin{array}{c}\mathrm{N}_{2} \mathrm{O} \text { emissions from volatilization and } \\
\text { re-deposition }\end{array}$ & 0.010 & $\mathrm{~kg} \mathrm{~N}_{2} \mathrm{O}-\mathrm{N} \mathrm{kg}^{-1} \mathrm{NH}_{3-} \mathrm{N}$ \\
\hline $\mathrm{EF}_{\mathrm{L}}$ & $\mathrm{N}_{2} \mathrm{O}$ emissions from $\mathrm{N}$ leaching & 0.011 & $\mathrm{~kg} \mathrm{~N}_{2} \mathrm{O}-\mathrm{N} \mathrm{kg}^{-1} \mathrm{~N}$ leached \\
\hline $\mathrm{F}_{\mathrm{A}}$ & $\begin{array}{l}\text { Fraction of applied } \mathrm{N} \text { lost as ammonia } \\
\text { (for ammonia-N based fertilizer) }\end{array}$ & 0.05 & $\begin{array}{c}\mathrm{kg} \mathrm{NH}_{3}-\mathrm{N}+\mathrm{NO}_{\mathbf{x}}-\mathrm{N} \mathrm{kg}^{-1} \\
\text { applied } \mathrm{N}\end{array}$ \\
\hline $\mathrm{N}_{\text {leached }}$ & Fraction of $\mathrm{N}$ lost by leaching & 0.24 & $\mathrm{Kg} \mathrm{N} \mathrm{kg}^{-1}$ applied $\mathrm{N}$ \\
\hline
\end{tabular}

\section{References}

1. Blunden, J.; Boyer, T. State of the Climate in 2020. Bull. Am. Meteorol. Soc. 2021, 102, S1-S475. [CrossRef]

2. Ciais, P.; Sabine, C.; Bala, G.; Bopp, L.; Brovkin, V.; Canadell, J.; Chhabra, A.; DeFries, R.; Galloway, J.; Heimann, M. Carbon and other biogeochemical cycles. In Climate Change 2013: The Physical Science Basis; Contribution of Working Group I to the Fifth Assessment Report of the Intergovernmental Panel on Climate Change; Cambridge University Press: Cambridge, UK, 2014; pp. 465-570.

3. European Comission. 2030 Climate \& Energy Framework. YEAR. Available online: https://ec.europa.eu/clima/policies/ strategies/2030_en (accessed on 10 December 2019).

4. European Comission. 2050 Long-Term Strategy. YEAR. Available online: https://ec.europa.eu/clima/policies/strategies/2050 _en (accessed on 10 December 2019).

5. Allerup, J. Sweden's Climate Act and Climate Policy Framework. 2019. Available online: http://www.swedishepa.se/ Environmental-objectives-and-cooperation/Swedish-environmental-work/Work-areas/Climate/Climate-Act-and-Climatepolicy-framework-/ (accessed on 10 December 2019).

6. Farand, C. Sweden Just Committed to Having Zero Carbon Emissions, and Perfectly Trolled Trump at the Same Time. 2017. Available online: http://www.independent.co.uk/news/science/sweden-pledges-greenhouse-gas-emissions-zero-2045-parisagreement-a7561111.html (accessed on 10 December 2019).

7. World Bioenergy Association. WBA Global Bioenergy Statistics 2020; World Bioenergy Association: Stockholm, Sweden, 2020 ; p. 64. Available online: https:/ / www.worldbioenergy.org/uploads/201210\%20WBA\%20GBS\%202020.pdf (accessed on 20 September 2021). 
8. Poplars and Willows: Trees for Society and the Environment; Isebrands, J.G.; Richardson, J. (Eds.) CABI: Boston, MA, USA; FAO: Rome, Italy, 2013; ISBN 978-1-78064-108-9.

9. Karp, A.; Shield, I. Bioenergy from Plants and the Sustainable Yield Challenge. New Phytol. 2008, 179, 15-32. [CrossRef]

10. Ventura, M.; Panzacchi, P.; Muzzi, E.; Magnani, F.; Tonon, G. Carbon Balance and Soil Carbon Input in a Poplar Short Rotation Coppice Plantation as Affected by Nitrogen and Wood Ash Application. New For. 2019, 50, 969-990. [CrossRef]

11. Don, A.; Osborne, B.; Hastings, A.; Skiba, U.; Carter, M.S.; Drewer, J.; Flessa, H.; Freibauer, A.; Hyvönen, N.; Jones, M.B.; et al. Land-Use Change to Bioenergy Production in Europe: Implications for the Greenhouse Gas Balance and Soil Carbon. Glob. Chang. Biol. Bioenergy 2012, 4, 372-391. [CrossRef]

12. FAO. Poplars and Other Fast-Growing Trees-Renewable Resources for Future Green Economies. Synthesis of Country Progress Reports; 25th Session of the International Poplar Commision, Berlin, Germany; Working Paper IPC/15; Forestry Policy and Resources Division, FAO, Rome: Italy, Federal Republic of Germany, 2016. p. 120. Available online: http:/ / www.fao.org/forestry/ipc2016/ en (accessed on 20 September 2021).

13. Daoson , M.; Boström, B. Vägen Till en Klimatpositiv Framtid. SOU 2020:4; Betänkande Från Klimatpolitiska Vägvalsutredningen: Stockholm, Sweden, 2020; ISBN 978-91-38-25019-8. Available online: https://bioenergyinternational.com/app/uploads/2019/0 5/Monica_Daoson_Bjorn_Bostrom.pdf (accessed on 20 September 2021).

14. Lindegaard, K.N.; Adams, P.W.R.; Holley, M.; Lamley, A.; Henriksson, A.; Larsson, S.; von Engelbrechten, H.-G.; Lopez, G.E.; Pisarek, M. Short Rotation Plantations Policy History in Europe: Lessons from the Past and Recommendations for the Future. Food Energy Secur. 2016, 5, 125-152. [CrossRef]

15. Nicolescu, V.-N. National Perspectives on Coppice from 35 EuroCoppice Member Countries; Albert Ludwig University: Freiburg, Germany, 2017; ISBN 978-3-9817340-1-0.

16. Dimitriou, I.; Rosenqvist, H.; Berndes, G. Slow Expansion and Low Yields of Willow Short Rotation Coppice in Sweden; Implications for Future Strategies. Biomass Bioenergy 2011, 35, 4613-4618. [CrossRef]

17. Hammar, T.; Ericsson, N.; Sundberg, C.; Hansson, P.-A. Climate Impact of Willow Grown for Bioenergy in Sweden. Bioenergy Res. 2014, 7, 1529-1540. [CrossRef]

18. Agostini, F.; Gregory, A.S.; Richter, G.M. Carbon Sequestration by Perennial Energy Crops: Is the Jury Still Out? Bioenergy Res. 2015, 8, 1057-1080. [CrossRef] [PubMed]

19. Dimitriou, I.; Mola-Yudego, B.; Aronsson, P.; Eriksson, J. Changes in Organic Carbon and Trace Elements in the Soil of Willow Short-Rotation Coppice Plantations. Bioenergy Res. 2012, 5, 563-572. [CrossRef]

20. Gauder, M.; Billen, N.; Zikeli, S.; Laub, M.; Graeff-Hönninger, S.; Claupein, W. Soil Carbon Stocks in Different Bioenergy Cropping Systems Including Subsoil. Soil Tillage Res. 2016, 155, 308-317. [CrossRef]

21. Georgiadis, P.; Vesterdal, L.; Stupak, I.; Raulund-Rasmussen, K. Accumulation of Soil Organic Carbon after Cropland Conversion to Short-Rotation Willow and Poplar. GCB Bioenergy 2017, 9, 1390-1401. [CrossRef]

22. Rytter, R.-M. The Potential of Willow and Poplar Plantations as Carbon Sinks in Sweden. Biomass Bioenergy 2012, 36, 86-95. [CrossRef]

23. Harris, Z.M.; Alberti, G.; Viger, M.; Jenkins, J.R.; Rowe, R.; McNamara, N.P.; Taylor, G. Land-Use Change to Bioenergy: Grassland to Short Rotation Coppice Willow Has an Improved Carbon Balance. GCB Bioenergy 2017, 9, 469-484. [CrossRef]

24. Walter, K.; Don, A.; Flessa, H. No General Soil Carbon Sequestration under Central European Short Rotation Coppices. GCB Bioenergy 2015, 7, 727-740. [CrossRef]

25. Rytter, R.-M.; Rytter, L.; Högbom, L. Carbon Sequestration in Willow (Salix Spp.) Plantations on Former Arable Land Estimated by Repeated Field Sampling and C Budget Calculation. Biomass Bioenergy 2015, 83, 483-492. [CrossRef]

26. Garrigues, E.; Corson, M.S.; Angers, D.A.; van der Werf, H.M.G.; Walter, C. Soil Quality in Life Cycle Assessment: Towards Development of an Indicator. Ecol. Indic. 2012, 18, 434-442. [CrossRef]

27. Henryson, K.; Sundberg, C.; Kätterer, T.; Hansson, P.-A. Accounting for Long-Term Soil Fertility Effects When Assessing the Climate Impact of Crop Cultivation. Agric. Syst. 2018, 164, 185-192. [CrossRef]

28. Huijbregts, M.A.J. Application of Uncertainty and Variability in LCA. Int. J. LCA 1998, 3, 273. [CrossRef]

29. Huijbregts, M.A.J. Part II: Dealing with Parameter Uncertainty and Uncertainty Due to Choices in Life Cycle Assessment. Int. J. LCA 1998, 3, 343-351. [CrossRef]

30. Baumann, H.; Tillman, A.-M. The Hitchhiker's Guide to LCA: An Orientation in Life Cycle Assessment Methodology and Application; Studentlitteratur: Lund, Sweden, 2004; ISBN 978-91-44-02364-9.

31. Cherubini, F.; Strømman, A.H. Life Cycle Assessment of Bioenergy Systems: State of the Art and Future Challenges. Bioresour. Technol. 2011, 102, 437-451. [CrossRef]

32. Ericsson, N.; Sundberg, C.; Nordberg, Å.; Ahlgren, S.; Hansson, P.-A. Time-Dependent Climate Impact and Energy Efficiency of Combined Heat and Power Production from Short-Rotation Coppice Willow Using Pyrolysis or Direct Combustion. GCB Bioenergy 2017, 9, 876-890. [CrossRef]

33. Ahmadi Moghaddam, E.; Ericsson, N.; Hansson, P.-A.; Nordberg, Å. Exploring the Potential for Biomethane Production by Willow Pyrolysis Using Life Cycle Assessment Methodology. Energy Sustain. Soc. 2019, 9, 6. [CrossRef]

34. Hammar, T. Climate Impacts of Woody Biomass Use for Heat and Power Production in Sweden. Ph.D. Thesis, Swedish University of Agricultural Sciences, Uppsala, Sweden, 2017. 
35. Ericsson, N.; Porsö, C.; Ahlgren, S.; Nordberg, Å.; Sundberg, C.; Hansson, P.-A. Time-Dependent Climate Impact of a Bioenergy System-Methodology Development and Application to Swedish Conditions. GCB Bioenergy 2013, 5, 580-590. [CrossRef]

36. Therasme, O.; Volk, T.A.; Eisenbies, M.H.; Amidon, T.E.; Fortier, M.-O. Life Cycle Greenhouse Gas Emissions of Ethanol Produced via Fermentation of Sugars Derived from Shrub Willow (Salix Ssp.) Hot Water Extraction in the Northeast United States. Biotechnol. Biofuels 2021, 14, 52. [CrossRef]

37. Yang, S.; Volk, T.A.; Fortier, M.-O.P. Willow Biomass Crops Are a Carbon Negative or Low-Carbon Feedstock Depending on Prior Land Use and Transportation Distances to End Users. Energies 2020, 13, 4251. [CrossRef]

38. Ericsson, N. Time-Dependent Climate Impact of Short Rotation Coppice Willow-Based Systems for Electricity and Heat Production. Ph.D. Thesis, Department of Energy and Technology, Swedish University of Agricultural Sciences, Uppsala, Sweden, 2015.

39. Murphy, F.; Devlin, G.; McDonnell, K. Energy Requirements and Environmental Impacts Associated with the Production of Short Rotation Willow (Salix Sp.) Chip in Ireland. GCB Bioenergy 2014, 6, 727-739. [CrossRef]

40. Heller, M.C.; Keoleian, G.A.; Volk, T.A. Life Cycle Assessment of a Willow Bioenergy Cropping System. Biomass Bioenergy 2003, 25, 147-165. [CrossRef]

41. Weih, M.; Nordh, N.-E. Characterising Willows for Biomass and Phytoremediation: Growth, Nitrogen and Water Use of 14 Willow Clones under Different Irrigation and Fertilisation Regimes. Biomass Bioenergy 2002, 23, 397-413. [CrossRef]

42. Adegbidi, H.G.; Volk, T.A.; White, E.H.; Abrahamson, L.P.; Briggs, R.D.; Bickelhaupt, D.H. Biomass and Nutrient Removal by Willow Clones in Experimental Bioenergy Plantations in New York State. Biomass Bioenergy 2001, 20, 399-411. [CrossRef]

43. Cunniff, J.; Purdy, S.J.; Barraclough, T.J.P.; Castle, M.; Maddison, A.L.; Jones, L.E.; Shield, I.F.; Gregory, A.S.; Karp, A. High Yielding Biomass Genotypes of Willow (Salix Spp.) Show Differences in below Ground Biomass Allocation. Biomass Bioenergy 2015, 80, 114-127. [CrossRef] [PubMed]

44. Baum, C.; Amm, T.; Kahle, P.; Weih, M. Fertilization Effects on Soil Ecology Strongly Depend on the Genotype in a Willow (Salix Spp.) Plantation. For. Ecol. Manag. 2020, 466, 118126. [CrossRef]

45. Weih, M.; Nordh, N.-E. Determinants of Biomass Production in Hybrid Willows and Prediction of Field Performance from Pot Studies. Tree Physiol. 2005, 25, 1197-1206. [CrossRef] [PubMed]

46. Andrén, O.; Kätterer, T. ICBM: The Introductory Carbon Balance Model for Exploration of Soil Carbon Balances. Ecol. Appl. 1997, 7, 1226-1236. [CrossRef]

47. Kahle, P.; Möller, J.; Baum, C.; Gurgel, A. Tillage-Induced Changes in the Distribution of Soil Organic Matter and the Soil Aggregate Stability under a Former Short Rotation Coppice. Soil Tillage Res. 2013, 133, 49-53. [CrossRef]

48. Rytter, R.-M.; Rytter, L. Growth, Decay, and Turnover Rates of Fine Roots of Basket Willows. Can. J. For. Res. 1998, 28 , 893-902. [CrossRef]

49. Caslin, B.; Finnan, J.; Johnston, C.; McCracken, A.; Walsh, L. Short Rotation Coppice Willow Best Practice Guidelines; Teagasc, Crops Research Centre, Ireland and AFBI, Agri-Food and Bioscience Institute: Belfast, UK, 2015; ISBN 1-84170-610-8.

50. Dimitriou, I.; Rutz, D. Sustainable Short Rotation Coppice: A Handbook; WIP Renewable Energies: Munich, Germany, 2015; ISBN 978-3-936338-36-2.

51. Börjesson, P.; Tufvesson, L.; Lantz, M. Life Cycle Assessment of Biofuels in Sweden; (LUTFD2/TFEM-10/3061-SE + (1-88); Department of Technology and Society, Environmental and Energy Systems Studies, Lund University: Lund, Sweden, 2010; Volume 70, ISBN 91-88360-96-2.

52. Phyllis2-ECN Phyllis Classification. YEAR. \#salix. Available online: https://phyllis.nl/Browse/Standard/ECN-Phyllis\#salix (accessed on 20 August 2020).

53. Nilsson, D.; Bernesson, S. Pelletering och Brikettering av Jordbruksråvaror: En Systemstudie (Processing Biofuels from Farm Raw Materials: A Systems Study); Rapport (Institutionen för energi och teknik, SLU), 001; Technical Report 001; Department of Energy and Technology, Swedish University of Agricultural Sciences: Uppsala, Sweden, 2008.

54. Djomo, S.N.; Kasmioui, O.E.; Ceulemans, R. Energy and Greenhouse Gas Balance of Bioenergy Production from Poplar and Willow: A Review. GCB Bioenergy 2011, 3, 181-197. [CrossRef]

55. Murphy, D.J.; Hall, C.A.S.; Dale, M.; Cleveland, C. Order from Chaos: A Preliminary Protocol for Determining the EROI of Fuels. Sustainability 2011, 3, 1888-1907. [CrossRef]

56. Buendia, E.E.C.; Tanabe, K.; Kranjc, A.; Jamsranjav, B.; Fukuda, M.; Ngarize, S.; Osako, A.; Pyrozhenko, Y.; Shermanau, P.; Federici, S. 2019 Refinement to the 2006 IPCC Guidelines for National Greenhouse Gas. Inventories; Intergovernmental Panel on Climate Change Report; IPPC: Geneva, Switzerland, 2019.

57. Manzoni, S.; Lindh, M.; Hoeber, S.; Weih, M. Salix Biomass and Nitrogen Content Measured in a Pot Experiment, Uppsala, Sweden, 2018-2019; Bolin Centre Database: Stockholm, Sweden, 2021; Dataset Version 1.0.

58. Andrén, O.; Kätterer, T.; Karlsson, T. ICBM Regional Model for Estimations of Dynamics of Agricultural Soil Carbon Pools. Nutr. Cycl. Agroecosyst. 2004, 70, 231-239. [CrossRef]

59. Kirchmann, H.; Persson, J.; Carlgren, K. The Ultuna Long-Term Soil Organic Matter Experiment, 1956-1991; Department of Soil Sciences, Reports and Dissertations—Swedish University of Agricultural Sciences; Springer: Uppsala, Sweden, 1994.

60. Kätterer, T.; Bolinder, M.A.; Andrén, O.; Kirchmann, H.; Menichetti, L. Roots Contribute More to Refractory Soil Organic Matter than Above-Ground Crop Residues, as Revealed by a Long-Term Field Experiment. Agric. Ecosyst. Environ. 2011, 141, 184-192. [CrossRef] 
61. Rytter, R.-M. Biomass Production and Allocation, Including Fine-Root Turnover, and Annual N Uptake in Lysimeter-Grown Basket Willows. For. Ecol. Manag. 2001, 140, 177-192. [CrossRef]

62. Rytter, R.-M.; Hansson, A.-C. Seasonal Amount, Growth and Depth Distribution of Fine Roots in an Irrigated and Fertilized Salix Viminalis L. Plantation. Biomass Bioenergy 1996, 11, 129-137. [CrossRef]

63. Han, C.; Young, S.L. Root Growth of Two Perennial Grass Types and Musk Thistle (Carduus Nutans) in Temperate Grasslands of North America. Invasive Plant Sci. Manag. 2014, 7, 387-397. [CrossRef]

64. Myhre, G.; Shindell, D.; Bréon, F.-M.; Collins, W.; Fuglestvedt, J.; Huang, J.; Koch, D.; Lamarque, J.-F.; Lee, D.; Mendoza, B.; et al. 2013: Anthropogenic and Natural Radiative Forcing. In Climate Change 2013: The Physical Science Basis; Contribution of Working Group I to the Fifth Assessment Report of the Intergovernmental Panel on Climate Change; Cambridge University Press: Cambridge, UK; New York, NY, USA, 2013; p. 82.

65. Yuan, C.; Wang, E.; Zhai, Q.; Yang, F. Temporal Discounting in Life Cycle Assessment: A Critical Review and Theoretical Framework. Environ. Impact Assess. Rev. 2015, 51, 23-31. [CrossRef]

66. Joos, F.; Prentice, I.C.; Sitch, S.; Meyer, R.; Hooss, G.; Plattner, G.-K.; Gerber, S.; Hasselmann, K. Global Warming Feedbacks on Terrestrial Carbon Uptake under the Intergovernmental Panel on Climate Change (IPCC) Emission Scenarios. Glob. Biogeochem. Cycles 2001, 15, 891-907. [CrossRef]

67. Röös, E.; Sundberg, C.; Hansson, P.-A. Uncertainties in the Carbon Footprint of Food Products: A Case Study on Table Potatoes. Int. J. Life Cycle Assess. 2010, 15, 478-488. [CrossRef]

68. Mueller, K.E.; Tilman, D.; Fornara, D.A.; Hobbie, S.E. Root Depth Distribution and the Diversity-Productivity Relationship in a Long-Term Grassland Experiment. Ecology 2013, 94, 787-793. [CrossRef]

69. Lettens, S.; Muys, B.; Ceulemans, R.; Moons, E.; Garcia, J.; Coppin, P. Energy Budget and Greenhouse Gas Balance Evaluation of Sustainable Coppice Systems for Electricity Production. Biomass Bioenergy 2003, 24, 179-197. [CrossRef]

70. Goglio, P.; Owende, P.M.O. A Screening LCA of Short Rotation Coppice Willow (Salix Sp.) Feedstock Production System for Small-Scale Electricity Generation. Biosyst. Eng. 2009, 103, 389-394. [CrossRef]

71. Heller, M.C.; Keoleian, G.A.; Mann, M.K.; Volk, T.A. Life Cycle Energy and Environmental Benefits of Generating Electricity from Willow Biomass. Renew. Energy 2004, 29, 1023-1042. [CrossRef]

72. Styles, D.; Jones, M.B. Energy Crops in Ireland: Quantifying the Potential Life-Cycle Greenhouse Gas Reductions of Energy-Crop Electricity. Biomass Bioenergy 2007, 31, 759-772. [CrossRef]

73. Boehmel, C.; Lewandowski, I.; Claupein, W. Comparing Annual and Perennial Energy Cropping Systems with Different Management Intensities. Agric. Syst. 2008, 96, 224-236. [CrossRef]

74. Börjesson, P.I.I. Energy Analysis of Biomass Production and Transportation. Biomass Bioenergy 1996, 11, 305-318. [CrossRef]

75. Gustavsson, L.; Börjesson, P.; Johansson, B.; Svenningsson, P. Reducing CO2 Emissions by Substituting Biomass for Fossil Fuels. Energy 1995, 20, 1097-1113. [CrossRef]

76. Matthews, R.W. Modelling of Energy and Carbon Budgets of Wood Fuel Coppice Systems. Biomass Bioenergy 2001, 21, 1-19. [CrossRef]

77. Heinsoo, K.; Merilo, E.; Petrovits, M.; Koppel, A. Fine Root Biomass and Production in a Salix Viminalis and Salix Dasyclados Plantation. Est. J. Ecol. 2009, 58, 27-37. [CrossRef]

78. Rytter, R.-M. The Effect of Limited Availability of N or Water on C Allocation to Fine Roots and Annual Fine Root Turnover in Alnus Incana and Salix Viminalis. Tree Physiol. 2013, 33, 924-939. [CrossRef]

79. Pacaldo, R.S.; Volk, T.A.; Briggs, R.D. Greenhouse Gas Potentials of Shrub Willow Biomass Crops Based on Below- and Aboveground Biomass Inventory Along a 19-Year Chronosequence. Bioenergy Res. 2013, 6, 252-262. [CrossRef]

80. Rytter, R.-M. Fine-Root Production and Turnover in a Willow Plantation Estimated by Different Calculation Methods. Scand. J. For. Res. 1999, 14, 526-537. [CrossRef]

81. Gregory, A.S.; Dungait, J.A.J.; Shield, I.F.; Macalpine, W.J.; Cunniff, J.; Durenkamp, M.; White, R.P.; Joynes, A.; Richter, G.M. Species and Genotype Effects of Bioenergy Crops on Root Production, Carbon and Nitrogen in Temperate Agricultural Soil. Bioenergy Res. 2018, 11, 382-397. [CrossRef]

82. Sevel, L.; Nord-Larsen, T.; Raulund-Rasmussen, K. Biomass Production of Four Willow Clones Grown as Short Rotation Coppice on Two Soil Types in Denmark. Biomass Bioenergy 2012, 46, 664-672. [CrossRef]

83. Pietrzykowski, M.; Woś, B.; Tylek, P.; Kwaśniewski, D.; Juliszewski, T.; Walczyk, J.; Likus-Cieślik, J.; Ochał, W.; Tabor, S. Carbon Sink Potential and Allocation in Above- and below-Ground Biomass in Willow Coppice. J. For. Res. 2021, 32, 349-354. [CrossRef]

84. Rytter, R.-M.; Rytter, L. Quantitative Estimates of Root Densities at Minirhizotrons Differ from Those in the Bulk Soil. Plant Soil 2012, 350, 205-220. [CrossRef]

85. Püttsepp, Ü.; Lõhmus, K.; Koppel, A. Decomposition of Fine Roots and $\alpha$-Cellulose in a Short Rotation Willow (Salix Spp.) Plantation on Abandoned Agricultural Land. Silva. Fenn. 2007, 41, 247. [CrossRef]

86. Pappas, C.; Maillet, J.; Rakowski, S.; Baltzer, J.L.; Barr, A.G.; Black, T.A.; Fatichi, S.; Laroque, C.P.; Matheny, A.M.; Roy, A.; et al. Aboveground Tree Growth Is a Minor and Decoupled Fraction of Boreal Forest Carbon Input. Agric. For. Meteorol. 2020, 290, 108030. [CrossRef]

87. Khan, S.A.; Mulvaney, R.L.; Ellsworth, T.R.; Boast, C.W. The Myth of Nitrogen Fertilization for Soil Carbon Sequestration. J. Environ. Qual. 2007, 36, 1821-1832. [CrossRef] 
88. Churchman, G.J.; Singh, M.; Schapel, A.; Sarkar, B.; Bolan, N. Clau Minerals as the Key to the Sequestration of Carbon in Soils. Clays Clay Miner. 2020, 68, 135-143. [CrossRef]

89. Chimento, C.; Almagro, M.; Amaducci, S. Carbon Sequestration Potential in Perennial Bioenergy Crops: The Importance of Organic Matter Inputs and Its Physical Protection. GCB Bioenergy 2016, 8, 111-121. [CrossRef]

90. Berhongaray, G.; Verlinden, M.S.; Broeckx, L.S.; Janssens, I.A.; Ceulemans, R. Soil Carbon and Belowground Carbon Balance of a Short-Rotation Coppice: Assessments from Three Different Approaches. GCB Bioenergy 2017, 9, 299-313. [CrossRef]

91. Qin, Z.; Dunn, J.B.; Kwon, H.; Mueller, S.; Wander, M.M. Soil Carbon Sequestration and Land Use Change Associated with Biofuel Production: Empirical Evidence. GCB Bioenergy 2016, 8, 66-80. [CrossRef]

92. Dimitriou, I.; Mola-Yudego, B.; Aronsson, P. Impact of Willow Short Rotation Coppice on Water Quality. Bioenergy Res. 2012, 5, 537-545. [CrossRef] 